\title{
Intervenciones preventivas en contextos recreativos nocturnos: revisión
}

\section{Preventive interventions in nightlife: a review}

\author{
I Amador Calafat; Montse Juan; Maria Angels Duch
}

| Irefrea (European Institute of Studies on Prevention)

Enviar correspondencia a:

Amador Calafat. Irefrea. Rambla, 15, 2 $3^{\mathrm{a}} 07003$

Palma de Mallorca. irefrea@irefrea.org recibido: enero 2009 aceptado: septiembre 2009

\section{RESUMEN}

Participar en la vida recreativa nocturna es una actividad cultural importante para muchos jóvenes. También es una actividad que interesa a la industria recreativa y a las corporaciones locales por los beneficios económicos, Pero estos aspectos positivos no impide que existan problemas que afectan a los jóvenes (abuso de alcohol y drogas, violencia, sexualidad de riesgo...) o a la propia actividad recreativa (ruido, consumo callejero de alcohol, vandalismo... Existen numerosas posibilidades preventivas, pero que sin embargo cuentan con escasas evaluaciones.

Hemos clasificado estas actividades preventivas en 11 categorias en función de su objetivo principal (centrados en los locales, educación, cumplir leyes, colaboración con la industria...) y se ha procedido a revisar la evidencia que avala cada tipo de intervención.

Intervenciones que han sido muy populares como proporcionar información o el testado de pastillas no están avaladas por la investigación. Otras que están siendo actualmente muy impulsadas por la industria como la dispensación responsable de bebidas o el conductor designado, tampoco tienen demostrada su eficacia, especialmente si no existe un sistema obligado de cumplimiento. Los programas comunitarios pueden ser efectivos, pero tiene problemas para conseguir su continuidad a medio plazo. Lo que se desprende de esta revisión es que la mejor combinación es la que incluye formación, cooperación y aplicación de la ley. Las medidas 'clásicas' (impuestos, control alcoholemia, prohibición consumo menores...) son eficaces y están basadas en evidencia. Es importante explorar intervenciones que influyan sobre la base cultural que sostiene la vida de noche. Pero este tipo de intervenciones no dependen de la voluntad o del buen hacer de los profesionales sino de cambios en la sociedad. El uso frecuente de programas populares ineficaces contribuyen más a aumentar el problema que a su solución y además tienen el efecto de dar una mala reputación a la prevención.

Palabras clave: drogas recreativas, prevención, diversión nocturna, evaluación, revisión.

\section{ABSTRACT}

Participating in nightlife it is a meaningful cultural activity for young people. Councils welcome a flourishing late-night entertainment industry. But there also problems related to the people involved (alcohol and drug abuse, violence, risky sex...) and to the recreational activity itself (noise, street drinking, vandalism...). Prevention intervention possibilities are numerous, and most have been implemented, however assessment of their outcomes is less common.

We have identified 11 types of prevention according to their main objective (venues centred, community, education, law enforcement, industry collaboration...) and we have reviewed the existing evidence in relation to each form of intervention.

Popular types of interventions as providing information or pill testing are not evidence based. Other interventions as Responsible beverage services or designated driver programmes, backed by the industry, are not exactly the most effective, especially if they are not enforced. Others like community approaches can be effective but it can be a problem how to achieve their continuity. From the present review, what emerges as the best strategy is the combination of training, cooperation and enforcement. 'Classical' measures (taxation, reduced BAC limits, minimum legal purchasing age...) are also evidence-based and effective.

Could be interesting to investigate interventions that address the cultural aspects of nightlife. But this sort of interventions do not depend on the will or the skills of professionals, and are more related to societal changes. The highly frequent use of popular but ineffective interventions contributes more to the problem than to its solution, and only facilitates giving preventive efforts a bad reputation.

Key words: recreational drugs, prevention, nightlife, evaluation, review. 


\section{INTRODUCCIÓN}

E las últimas décadas la vida nocturna de los fines de semana ha sido una de las actividades de ocio más importantes para los jóvenes de numerosos países occidentales. Muchos experimentan las noches de los fines de semana como su propio mundo, lo cual entra en conflicto con el resto de la semana, identificada con el mundo adulto (en el que la gente trabaja, estudia, está con la familia, etc.) Dependiendo de las ciudades, los jóvenes europeos dedican entre 4 y 7 horas cada noche del fin de semana a actividades de ocio de este tipo (Calafat, Bohrn, Juan, Kokkevi, Maalsté, Mendes et al., 1999). "Esos fines de semana de excesos combinan la liberación simbólica, educativa (aprendemos a moderarnos experimentando excesos), funcional y catártica de la semana laboral y están condicionados por nuestra posición estructural en la sociedad" (Measham, 2004). Las noches de los fines de semana son contextos de socialización cada vez más importantes en los que los jóvenes adquieren capital social. Parker (2003) incluso afirma que este tipo de consumidores recreativos realizan mejor la transición a la vida adulta que sus coetáneos abstemios. Shedler y Block (1990) sostienen un argumento igualmente provocador, según el cual las personas que prueban las drogas son psicológicamente más sanas que las que se abstienen, basándose en un estudio longitudinal sobre una muestra de 85 individuos. No obstante, dicho argumento no se corroboró en un estudio de replicación longitudinal realizado sobre una muestra de 2071 adolescentes (Milich, Lynam, Zimmerman, Logan, Martin, Leukefeld et al., 2000), ni en otro estudio en el que los clásicos factores de riesgo mantienen su prevalencia entre los consumidores de ocio recreativo (Calafat, Fernández, Juan y Becoña, 2008). Afortunadamente, estas cosas no hay que entenderlas en blanco y negro. Por ejemplo, una misma ocasión en la que se consume alcohol puede tener consecuencias positivas y negativas, que a veces se entremezclan (Graham, 2001).

Participar en la vida nocturna es una importante actividad cultural para los jóvenes. Los ayuntamientos ven con buenos ojos la ufloreciente industria de la diversión nocturna" (Greater London Authority, 2002). Pero ese florecimiento y las personas relacionadas con los ambientes recreativos también plantean problemas. Este artículo se centrará en la forma de minimizar esos problemas, revisando la eficacia de diferentes tipos de supuestas intervenciones preventivas. Empezaremos identificando las principales áreas que presentan problemas:

- Problemas de salud (heridas, deterioro auditivo, trastornos mentales, hipertermia, embriaguez, consumo de drogas, etc.). Existe una relación sólidamente documentada entre determinados ambientes recreativos nocturnos y el consumo de sustancias sintéticas, así como pruebas claras de una elevada prevalencia de consumo de sustancias recreativas en relación con la participación en estos ambientes (Bellis, Hale, Bennet, Chaves y Kilfoyle, 2000; Calafat et al., 1999; Forsyth, Barnard y McKeganey,1997; Tossmann, Bold y Tensil,1999). «Investigaciones centradas en jóvenes europeos que frecuentan eventos musicales demuestran

\section{INTRODUCTION}

W eekend nightlife has been for the last few decades one of the most important leisure activities of young people in many Western countries. Many of them truly experience weekend nights as their own world, which conflicts with the rest of the week, identified with the adult world (where people work, study, stay with the family, etc.). Depending on the city, young Europeans are devoting between 4 and 7 hours every weekend night to leisure pursuits of this kind (Calafat, Bohrn, Juan, Kokkevi, Maalsté, Mendes et al., 1999). 'These weekends of excess combine the symbolic, educational (we learn moderation through experiencing excess), and the functional cathartic release from the working week, and are bounded by our structural position in society' (Measham, 2004). Weekend nights are becoming important socialization contexts in which young people acquire social capital. Parker (2003) is even of the opinion that this kind of recreational user may make a better transition to adult life than his/her abstemious peers. Shedler and Block (1990) make the similarly provocative proposal that people who experiment with drugs are psychologically healthier than abstainers, on the basis of a longitudinal study with a sample of 85 individuals. Nevertheless, this proposal could not be corroborated in a longitudinal replication study made with a sample of 2071 adolescents (Milich, Lynam, Zimmerman, Logan, Martin, Leukefeld et al., 2000), or in another study in which classic risk factors still maintain their importance among recreational users (Calafat, Fernández, Juan and Becoña, 2008). Fortunately, the issue is not black and white. For example, in the case of drinking alcohol, a single drinking occasion may have positive and negative consequences, and these consequences may be interrelated (Graham, 2001).

Participating in nightlife it is a meaningful cultural activity for young people. Councils welcome a 'flourishing late-night entertainment industry' (Greater London Authority, 2002). But there also problems related to the flourishing of this industry and to the people involved in such recreational contexts. This paper will focus precisely on how to minimise these problems, through a review of the effectiveness of different proposals for preventive intervention. We begin by identifying the principal areas in which problems arise:

- Health problems (injuries, hearing damage, mental disorders, heat stroke, drunkenness, drug use, etc.). There is a well-documented relationship between specific nightlife recreational environments and synthetic substance use, as well as evidence of a high prevalence of recreational substance use (Bellis, Hale, Bennet,Chaves and Kilfoyle, 2000; Calafat et al., 1999; Forsyth, Barnard, \&t McKeganey, 1997; Tossmann, Bold, \&t Tensil, 1999). "Research studies targeted at young people in the EU who attend dance music events consistently report much higher prevalence of drug use than that found in surveys of the general population. This appears to be the case 
invariablemente una prevalencia mucho más elevada del consumo de drogas que la registrada entre la población general. Ocurre lo mismo en todos los países en los que se han realizado investigaciones similares» (EMCDDA, 2006).

- La violencia nocturna es cada vez más preocupante. La investigación demuestra que el momento culminante de delitos violentos se produce en las noches de los fines de semana y los lugares preferidos son los pubs y discotecas y sus alrededores (Allen, Nicholas, Salisbury y Wood, 2003). En el Reino Unido la quinta parte de los ataques violentos se producen en el interior o cerca de un pub 0 una discoteca, y casi la mitad de todos los incidentes de violencia y desórdenes ocurren las noches de los fines de semana (Maguire y Nettleton, 2003). Un pequeño número de establecimientos autorizados registran la mayor parte de alborotos y agresiones (Briscoe y Donnelly, 2001; Graham y Wells, 2001, Jochelson, 1997), pero es evidente que quienes participan en actividades violentas seleccionan los locales (Hughes, Bellis, Calafat, Juan, Schnittzer y Anderson, 2008).

- Sexo inseguro o 'no deseado'. Para muchos clientes de discotecas el consumo de sustancias forma parte integral de su estrategia de acceso al sexo. Incluso tienen cierta idea de los efectos que deben esperar de cada droga sobre la sexualidad. Las drogas recreativas y el consumo concentrado de alcohol alteran sus decisiones sexuales e incrementan las posibilidades de practicar sexo inseguro o del que posteriormente se arrepienten (Bellis, Hughes, Calafat, Juan, Ramón, Rodríguez et al., 2008; Calafat, Juan, Becoña, y Mantecón, 2008).

- El transporte a y desde las zonas de ocio provoca importantes problemas, sobre todo porque el medio de transporte más frecuente $(37,5 \%)$ son los automóviles particulares, de acuerdo con una muestra de 1363 clientes habituales de establecimientos nocturnos de nueve ciudades europeas en 2006. En el último mes, el $18 \%$ de la muestra había conducido en estado de embriaguez, el 13\% bajo el efecto de las drogas, y el $37 \%$ había viajado en un coche conducido por alguien embriagado o bajo los efectos de las drogas (Calafat, Blay, Juan, Adrover, Bellis, Hughes et al., 2009).

- Consumo de alcohol entre menores de edad. La venta de bebidas alcohólicas a los menores de edad es un fenómeno relativamente corriente. A pesar de que la edad mínima para consumir alcohol es de 21 años en Estados Unidos, los estudios demuestran que entre el 30 y el $70 \%$ de los establecimientos de venta de bebidas atienden a compradores por debajo de dicha edad, dependiendo en parte de la ubicación geográfica (Paschall, Grube, Black y Ringwalt, 2007). En la isla de lbiza el $80 \%$ de los estudiantes de 17 años han entrado en una discoteca, aunque la ley lo prohibe, siendo la edad de prohibición sensiblemente inferior (18) de la americana (Villar, 2008).

- Molestias sociales (ruido, consumo de alcohol en la calle, vandalismo, etc.). La presencia de locales recreativos incide de forma positiva y negativa a la vez en las zonas en las que se ubican. La expansión de la economía del ocio nocturno en el centro de la ciudad de Manchester ha crea- in all of the countries where such surveys have been conducted" (Annual report 2006, EMCDDA).

- Nightlife violence is a topic of increasing concern. Research consistently shows the peak time for violent offence is weekend nights and the peak location is in and around pubs and clubs (Allen, Nicholas, Salisbury and Wood, 2003). In the United Kingdom one fifth of all violent assaults take place in or around a pub or club, and almost half of all incidents of violence and disorder occur on weekend nights (Maguire and Nettleton, 2003). A small number of licensed premises account for most disorder and assault (Briscoe \&t Donnelly, 2001; Graham \& Wells, 2001, Jochelson, 1997), but is true that those involved in violence tend to select the venues they attend (Hughes, Bellis, Calafat, Juan, Schnittzer and Anderson, 2008).

- Unsafe and involuntary sex. For many clubbers substance use has become an integral part of their strategic approach to sex. They even have a certain idea of how each drug functions within sexuality. Recreational drug use and binge drinking alter their sexual decisions and increase their chances of unsafe and regretted sex (Bellis, Hughes, Calafat, Juan, Ramon, Rodriguez et al., 2008; Calafat, Juan, Becoña, and Mantecón, 2008).

- Transport to and from recreational areas is related to substantial problems, mainly because the most frequent (37.5\%) form of transport used when going out are private cars, according to the results from a sample of 1363 regular nightlife users from nine European cities in 2006. During the last month, the $18 \%$ of the sample had driven while drunk, $13 \%$ had driven under the influence of drugs, and $37 \%$ had taken a lift from someone drunk or under the influence of drugs (Calafat, Blay, Juan, Adrover, Bellis, Hughes et al., 2009).

- Underage drinking. The sale of drink to those legally underage is a relatively common phenomenon. Despite a national minimum drinking age of 21 , US research indicates that 30 to 70 percent of alcohol outlets may sell to underage buyers, depending in part on their geographical location (Paschall, Grube, Black and Ringwalt, 2007). On the island of Ibiza, $80 \%$ of 17-year-old students have been to a disco, even though this is against the law (Villar, 2008).

- Social nuisance (noise, street drinking, vandalism, etc.). Neighbourhoods are strongly affected both positively and negatively by the presence of recreational venues. The expansion of the night-time economy in Manchester city centre has created an estimated 12,000 jobs for bar, waiting, catering and security staff. But of course all this development has given rise to problems. Some people have the feeling that cities are being hijacked or colonised by the young, and refer to the 'so-called lager lout phenomenon' (Worpole, 1992). 
do unos 12.000 puestos de trabajo de camareros de barra y sala, servicio de comidas y personal de seguridad. Pero todo ese desarrollo ha provocado problemas. Algunos tienen la sensación de que las ciudades han sido tomadas o colonizadas por los jóvenes y aluden al «llamado fenómeno de los gamberros de la litrona" (Worpole, 1992).

En las últimas décadas el sector del ocio nocturno ha experimentado numerosos cambios cuantitativos y cualitativos. El crecimiento de la industria recreativa ha sido enorme, no sólo en los lugares turísticos tradicionales, sino en la mayoría de las ciudades occidentales. En la actualidad la oferta no se limita a los típicos bares. La música y el baile tienen una fuerte presencia. La clientela también ha cambiado: es mucho más joven, y los horarios son más nocturnos. Iniciativas comerciales, como la nueva comercialización de las bebidas alcohólicas y el rediseño y cambio de imagen de los locales autorizados por parte de la industria de bebidas alcohólicas, dieron lugar a la transformación de la economía del ocio nocturno a finales de los años 90 para atraer a una nueva generación de jóvenes bebedores, tanto hombres como mujeres (Measham, 2004). En consecuencia, una significativa proporción del consumo total de alcohol y drogas ilegales entre la juventud europea se vincula a las actividades recreativas nocturnas (Fountain y Griffiths, 1997).

\section{INTERVENCIONES PREVENTIVAS}

La necesidad de intervenir para abordar problemas en los bares (embriaguez, violencia...) no es un fenómeno nuevo. En muchos paises la venta de alcohol en bares es una actividad regulada. La regulación de permisos de venta de alcohol era un sistema de intervención muy habitual para controlar problemas en los bares. Sin embargo, hay pocos estudios que valoren las políticas de intervención en los locales autorizados (Graham, 2000).

Es bien sabido que en las últimas décadas el ocio no se centra exclusivamente en los adultos, los bares y el alcohol. Las variantes modernas de ocio dirigidas a los jóvenes y basadas en música, discotecas, baile y otras actividades nocturnas juegan un papel esencial, sobre todo en zonas turísticas como las Islas Baleares. En los años 70 y especialmente en los 80 este modelo experimentó una gran expansión en Europa, dando lugar al cambio de los hábitos de diversión de los jóvenes de forma muy visible (Collin $\mathrm{M}$, 1997).

En cuanto actividad en la que participan amplios sectores de jóvenes, con buenas habilidades sociales y excelentes niveles de integración, la impresión es que no genera demasiados problemas. $Y$ es cierto, en parte, pero no es menos cierto que un determinado porcentaje de jóvenes consumen alcohol y e incluso los problemas afectan a la mayoría, puesto que aproximadamente el $75 \%$ de los que salen se emborrachan al menos una vez al mes (Calafat, Fernández, Juan, Anttila, Arias, Bellis, Bohrn, et al., 2003), lo cual aumenta las probabilidades de que practiquen conductas de riesgo. Por ejemplo, es muy habitual beber y conducir en ambientes de ocio nocturno (Calafat, Blay, Juan, Adrover, Bellis, Hughes et al., 2009).
During recent decades the nightlife sector has seen a good deal of quantitative and qualitative changes. The growth experienced by the recreational industry is enormous, and not only in traditional tourist places, but indeed in most cities in the West. Furthermore, what is now on offer goes beyond traditional bars. Music now has a strong presence, as well as dancing. The type of clientele has changed, insofar as it is much younger, and the hours are more nocturnal. Commercial developments, such as the recommodification of alcoholic drinks and the redesign and rebranding of licensed leisure venues by the alcoholic beverage industry, resulted in the transformation of the night-time economy in the late 1990s to appeal to a new generation of young drinkers both male and female (Measham, 2004). In consequence, a substantial proportion of the total use of alcohol and illegal drugs among youth in Europe occurs in relation to night-time recreational activity (Fountain and Griffiths, 1997).

\section{PREVENTIVE INTERVENTIONS}

The need to intervene to deal with problems in bars (drunkenness, violence...) is far from being a new phenomenon. The fact is that in many countries the sale of alcohol in bars is a regulated activity. The regulation of licences to sell alcohol has been a very common system of intervention for controlling bar-related problems. Nevertheless, there has been relatively little assessment of research on intervention policy as it applies to licensed premises (Graham, 2000).

However, and as is well known, entertainment over recent decades is no longer focused exclusively on adults, bars and alcohol. Modern forms of entertainment aimed at young people and involving music, discos, dancing and other nightlife activities play a central role, and especially so in summer tourist areas such as the Balearic Islands. During the 1970s and particularly the 1980s in Europe this model saw enormous expansion, eventually changing young people's entertainment habits in a highly visible way (Collin M, 1997).

As an activity involving broad sectors of young people, with good social skills, and good levels of integration, the impression is that there are few problems around. This is largely true, but no less true is the fact of a certain percentage of young people using alcohol and drugs in an abusive and uncontrolled manner. But also, even among the majority problems can emerge, since about $75 \%$ of people go out to get drunk at least once a month (Calafat, Fernandez, Juan, Anttila, Arias, Bellis, Bohrn, et al., 2003), making it more likely for them to engage in risky behaviours. For example, drinking and driving in relation to nightlife is a common behaviour (Calafat, Blay, Juan, Adrover, Bellis, Hughes et al., 2009). 
En un estudio (Calafat et al., 2003) realizado hace unos años sobre una muestra de 40 programas de prevención concernientes a ambientes y actividades recreativas nocturnas de diez países europeos, no se encontró ninguna iniciativa basada en la evidencia. El principal objetivo del ochenta por cien de las intervenciones era proporcionar información sobre las drogas y reducir el daño asociado a su consumo. Sólo dos programas se centraron de forma explícita en reducir el consumo de drogas. La mayoría se dirigieron independientemente tanto a consumidores como a no consumidores, y el $72 \%$ utilizaron folletos, opúsculos, comunicaciones con franqueo pagado o carteles. La distribución de la información fue casi siempre directa. En otros casos se colocó en locales públicos (puestos en discotecas, bares, tiendas de ropa y otros lugares frecuentados por jóvenes). Nueve programas tenían página web propia. El asesoramiento de profesionales se incluyó en casi el 30\% de los programas, y aproximadamente el 40\% incluyeron propuestas alternativas (deportes, talleres...) a los ambientes de ocio nocturno como factor de protección contra el consumo de drogas. El 24\% de los programas recurrieron a iguales, sobre todo para distribuir la información.

En 2003 un estudio de la EMCDDA (2009) sobre respuestas selectivas en entornos recreativos demostró que de 78 proyectos ejecutados por 15 países europeos, 52 tenian como principal objetivo minimizar el daño y 26 la prevención y reducción del consumo de drogas. Casi la mitad de los proyectos se centraban en proporcionar información.

\section{TIPOS DE INTERVENCIÓN}

Las posibilidades de intervención son numerosas y la mayoria se han llevado a la práctica; sin embargo, casi nunca se valoran sus resultados. La clasificación que se ofrece a continuación es una de las posibles, y en cualquier caso siempre existe cierto grado de superposición. Por ejemplo, la intervención comunitaria puede referirse a locales, servicios de urgencias, iniciativas culturales, etc. Los programas tienen a veces diferentes componentes y en ciertos casos es aconsejable revisar la eficacia de cada componente.

1. Locales

a. Programas de formación del personal de los locales, incluyendo la gerencia. Normas de la casa.

b. Códigos de prácticas y otros acuerdos.

c. Horas de apertura. Capacidad de los locales.

d. Entorno físico y contextual.

e. Análisis de pastillas.

2. Intervenciones en la comunidad y en multicomponentes.

3. Educativas (educación de clientes, en la escuela, entre iguales, etc.)y campañas.

4. Servicios de urgencias, servicios médicos y de primeros auxilios.

5. Control de licencias, aplicación de la ley y control de menores de edad.

6. Contexto, ambientes, vecindario (transporte, iluminación...)
In a review (Calafat et al., 2003) carried out a few years ago on a sample of 40 prevention programs addressing the recreational context and activities in 10 different European countries, none of the initiatives were evidence-based. Eighty percent had as their main objective to provide information on drugs and to reduce harm associated with their use. There were only two programmes with an explicit focus on cutting down the use of drugs. Most of them targeted users and non-users independently and 72\% used pamphlets, flyers, freepost or posters. Distribution was generally direct, with information handed out to the target population. In other cases it was placed in public venues (stands in discos, bars, clothes outlets and other places frequented by the young). Nine of the programmes in this survey had their own websites. Counselling by professionals was included in nearly $30 \%$ of the programmes, and around $40 \%$ included some proposal encouraging an alternative (sports, workshops...) to the nightlife leisure environment as a protection factor against drug use. Twenty-four percent of the programmes used peers, mainly for distributing the information.

In 2003 an EMCDDA (2009) survey on selective responses in recreational settings showed that of 78 projects reported by 15 European countries, 52 reported harm minimisation as their main objective and 26 prevention and reduction of the use of drugs. In over half of the projects the main activity was the provision of information.

\section{TYPES OF INTERVENTION}

The intervention possibilities are numerous, and most have been implemented; however, assessment of their outcomes is less common. The classification shown below is a possible one among others, and in any case there is naturally some degree of overlap. Community intervention can be related to venues, emergency rooms, cultural approaches, and so on. Programmes can also sometimes be multi-component, and in such cases it may be useful to review what we know about the effectiveness of each component.

1. Venues
a. Bar staff and management training programmes. House policies
b. Code of practice and other agreements
c. Opening hours. Venue density.
d. Physical and contextual
e. Pill-testing

2. Community and multi-component interventions

3. Education (patron education, in-school education, peer education, etc.) and campaigns.

4. Emergency rooms, medical and first-aid services.

5. Licensing, Law enforcement and Underage control.

6. Context, environments, neighbourhood (transport, lighting...) 
7. Programas contra la conducción bajo efectos del alcohol.

8. Implementación de políticas; colaboración con la industria.

9. Programas alternativos.

10. Enfoques culturales.

11. Medidas de prevención «clásicas».

A continuación, analizaremos las evidencias que existen sobre cada una de estas formas de intervención.

\section{1.a Programas de formación del personal y de la gerencia. Servicio Responsable de Bebidas (SRB)}

Existen problemas relacionados (SRB), entre ellos la baja proporción personal/clientes (Homel y Clarck, 1994; Graham, Bernards, Osgood, Homel y Purcell, 2005), la dispensación de bebidas a personas en estado de embriaguez (Homel y Clark, 1994), la actitud hostil y agresiva del personal (Homel, Tomsen y Thommeny, 1992; Wells, Graham, West, 1998), personal mal preparado y sin coordinación (Homel et al., 1992), elevada proporción de personal masculino, y la presencia de "gorilas" (Homel y Clark, 1994; Quigley, Leonard, Collins, 2003). Casi un tercio de los incidentes violentos registrados en locales autorizados implican a el personal de puerta, muchas veces como supuestos provocadores (Maguire y Nettleton, 2003).

La formación del personal es uno de los tipos de intervención más extendidos para reducir problemas en los locales. El estado de Oregón impuso la formación a todos los expendedores de alcohol (y durante un año a todos los dueños/gerentes) desde diciembre de 1986. Se observó una reducción estadísticamente significativa en los accidentes de tráfico nocturnos (vinculados a altas tasas de alcohol) a finales de 1989, tras la puesta en práctica de la formación obligatoria de los empleados (Holder y Wagenaar, 1994). Otros estudios subrayan los beneficios de la formación del personal (Gliksman, McKenzie, Single et al., 1993), aunque los efectos disminuyen al cabo de 4 años (Buka y Birdthistle, 1999). La capacidad del personal de puertas para rechazar a clientes afectados por el consumo de drogas se valoró utilizando dos actores, obteniéndose una cifra de referencia de rechazo del 7,5\%, frente al 27\% después de la intervención (Gripenberg, Wallin y Andreasson, 2007).

Un estudio sistemático de Shults (2001), anterior al de Cochrane (véase más adelante), examinó la eficacia de la formación del personal de los locales a la hora de reducir la conducción bajo los efectos del alcohol. Se incluyeron cinco estudios controlados, tres de ellos no aleatorios. Se llegó a la conclusión de que uexisten pruebas suficientes de que la formación del personal cara a cara, si se acompaña de un apoyo fuerte y activo de la dirección de los locales, es eficaz en la reducción del nivel de embriaguez de los clientes".

Otros estudios, sin embargo, no son tan positivos. Según Graham (2000) o Homel (2001) la formación del personal no produce efectos o produce efectos muy limitados. Según

\section{Drink-Driving programmes}

8. Policing; collaboration with the industry.

9. Alternative programmes.

10. Cultural approaches

11. 'Classical' prevention measures.

We shall continue by reviewing the existing evidence in relation to each of these forms of intervention.

\section{1.a Bar staff and management training programmes. Responsible Beverage Service (RBS)}

Several issues related to bar staff have been linked to problems, including low staff/patron ratio (Homel and Clarck, 1994; Graham, Bernards, Osgood, Homel and Purcell, 2005), staff serving to intoxicated people (Homel and Clark, 1994), hostile and aggressive staff (Homel, Tomsen and Thommeny, 1992; Wells, Graham, West, 1998), staff who are poorly trained and poorly coordinated (Homel et al., 1992), a high proportion of male staff, and the presence of 'bouncers' (Homel and Clark, 1994; Quigley, Leonard, Collins, 2003). Over one third of violent incidents inside licensed premises involve door staff, often as alleged perpetrators (Maguire and Nettleton, 2003).

Training of staff has been one of the most widely implemented types of intervention for reducing problems in the venues. The state of Oregon introduced training for all alcohol servers (and for one year all owners/managers) from December 1986. They found statistically significant reductions in single-vehicle night-time traffic accidents (those with high percentage of alcohol involvement) by the end of 1989, following the implementation of the compulsory server-training policy (Holder and Wagenaar, 1994). Other studies also support the benefits of staff training (Gliksman, McKenzie, Single et al., 1993), even if the effects are diminished after 4 years (Buka and Birdthistle, 1999). When training of door staff to reject drug-useimpaired patrons was assessed using two actors, the baseline figure for rejection was 7.5\%, compared to $27 \%$ at post-test (Gripenberg, Wallin and Andreasson, 2007).

A systematic review by Shults (2001), prior to the Cochrane review (see below), examined the effectiveness of server training in reducing drink-driving. Five controlled studies were included, three of which were non-randomised. The review concluded that 'there is sufficient evidence that face to face server training, when accompanied by strong and active management support, is effective in reducing the level of intoxication in patrons'.

However, other findings are not so positive. According to Graham (2000) or Homel (2001), server training has no effect, or the effects are quite limited. The results, according 
estos autores los resultados no demuestran que la formación influya en la ingesta de alcohol. Las medidas de fuerza surtieron mayor efecto. Pero la formación del personal mostró su eficacia en la reducción de la violencia (Wallin y Andréasson, 2005).

Una revisión de Cochrane (Ker y Chinnock, 2008) analizó todos los estudios previos que comparaban los locales en los que los empleados habían participado en intervenciones para facilitar un consumo sensato de alcohol y/o prevenir la violencia con los locales que no habían recibido dichas intervenciones. Encontraron 20 estudios válidos y llegaron a la conclusión de que no hay evidencia fiable de que las intervenciones en los locales que sirven alcohol sean eficaces en la prevención de la violencia. La eficacia de las intervenciones sobre el consumo de alcohol de los clientes no resultó concluyente. Hay indicios de un mejor comportamiento de los empleados, pero es difícil predecir su efecto sobre el riesgo real de violencia. Uno de los problemas fundamentales es que, con el tiempo, las intervenciones dejan de hacerse; de ahi que las intervenciones obligatorias o las que ofrecen incentivos surtan mayor efecto. Téngase en cuenta que, por lo general, el trabajo en los bares está mal pagado y que hay una elevada rotación del personal.

Según Mosher (2002) los requisitos mínimos del SRB son:

1. Facilitar la información básica a los empleados de los locales.

2. Utilizar técnicas conductistas de cambio/comunicación (informar únicamente disminuye las posibilidades de cambiar la conducta o de perfeccionar habilidades). Hay que enseñar habilidades concretas (negarse a servir alcohol a clientes embriagados). Conviene utilizar técnicas activas (como la representación de papeles).

3. Atención tanto a los empleados como a los gerentes. Hay que incluir a los gerentes porque son responsables de la supervisión de los empleados y, por tanto, deben estar familiarizados con las técnicas.

4. Contemplar el desarrollo de normas por parte de la gerencia. Los gerentes deben elaborar normas de la casa por escrito, porque aumentan las posibilidades de poner en práctica la SRB en el establecimiento.

5. La duración mínima de una SRB eficaz es de 4 horas.

Hay que tener en cuenta que la cooperación de la gerencia de los locales es difícil de conseguir, a menos que sea obligatoria o que exista una fuerte presión social. Según Graham (2000), los dueños de los bares, los gerentes y el personal a) no suelen cambiar voluntariamente; b) casi nunca cooperan al cien por cien con las intervenciones; $c$ ) no cambian gran cosa tras la mayoría de las intervenciones; y d) no mantienen los cambios después de las intervenciones debido a factores como la competencia y las exigencias de los clientes. to these authors, do not show that RBS training alone has produced effects on alcohol intake. Clearly, enforcement was better. However, server training was probably effective in the reduction of violence (Wallin and Andréasson, 2005).

A Cochrane review (Ker and Chinnock, 2008) examined all studies which compared server settings receiving an intervention aimed at facilitating sensible alcohol consumption and/or preventing injuries, with server settings not receiving such an intervention. The authors found 20 studies, and concluded that there is no reliable evidence that interventions in the alcohol server setting are effective in preventing injuries. The effectiveness of the interventions on patron alcohol consumption was found to be inconclusive. There is some indication of improved server behaviour, but it is difficult to predict what effect this might have on actual injury risk. Lack of compliance with interventions appears to be a particular problem; hence, mandated interventions or those with associated incentives for compliance may be more likely to show an effect. It should be considered that bar work is generally low-paid, and that staff turnover is high.

Minimum requirements for RBS would be, according to Mosher (2002):

1. Cover all basic information with servers

2. Use behavioural change/communication techniques (by simply providing information the chances of promoting behaviour change or increasing skills is limited). Specific skills (refusing alcohol to an intoxicated patron) should be taught. Active techniques (e.g., role playing) should be used,

3. Focus on both managers and servers. Managers should be targeted because they are responsible for supervising the servers, so that they should be familiarised with the techniques.

4. Include policy development for managers. Managers should develop written house policies. This increases the chances of implementing RBS at the establishment.

5. The minimum length for effective RBS is four hours.

It must also be taken into account that cooperation from venue managers is often difficult to obtain, unless the scheme is mandatory or there is strong social pressure. According to Graham (2000), bar owners, managers and staff a) do not usually volunteer to change, b) often do not cooperate fully with interventions; c) typically do not change very much as a result of most interventions; and d) often do not sustain changes beyond interventions because of factors such as competition and patron demand. 


\section{1.b Códigos de práctica y otros acuerdos}

Las asociaciones de bares de diferentes paises (Australia, Reino Unido, Suecia...) han adoptado normas, generalmente de forma voluntaria. Se trata de un primer paso importante, pues con él la industria reconoce que tiene un papel que jugar y una responsabilidad en la prevención del daño. Es una práctica muy extendida en Australia, donde se han efectuado muchos estudios. Por desgracia, evolución de la puesta en marcha de los códigos de práctica voluntaria no demuestra su eficacia (Graham, 2000; Wilkins y Sweetsur, 2009). A pesar de la existencia de unos códigos de práctica para la Publicidad Responsable de Licores en una ciudad australiana, un seguimiento de ocho semanas demostró que existían numerosos ejemplos de publicidad que quebrantaba tanto el espíritu como la letra de las normas. Del mismo modo, el sistema de control del cumplimiento de los códigos de práctica es básicamente inadecuado (Jones y Lynch, 2007).

Pero algunas experiencias de colaboración con la industria, en las que las normas son obligatorias, resultan prometedoras (Lang y Rumbold, 1997; Wallin, 2005). Un interesante documento de consulta, elaborado por el Ministerio del Interior británico y la KPMG (2008) es el estudio "Normas de responsabilidad social para la producción y venta de bebidas alcohólicas", distribuido en 2005. Los cinco principios de una buena reglamentación son: proporcionalidad, responsabilidad, coherencia, transparencia y focalización. Los modelos más eficaces tienen estructuras propias, independientes de las instituciones de la industria. Pero un conjunto de normas administradas por una organización empresarial, si se estructura y ejecuta debidamente, es mejor que nada. Para que la autorregulación sea obedecida ha de castigar el incumplimiento con sanciones adecuadas, importantes y significativas desde el punto de vista comercial .

\section{1.c Horarios de apertura}

La limitación de las horas de la apertura es una forma tradicional de regulación en algunos paises como Reino Unido. En las horas con mayor número de delitos relacionados con el alcohol, el cierre tardío de los establecimientos se relaciona con tasas más elevadas de alcohol en sangre entre los bebedores propensos a sufrir daños provocados por el alcohol (Chikritzhs y Stockwell, 2007). La prohibición de la venta de alcohol a partir de las 11 p.m. produjo una reducción de casi nueve muertes al mes en Diadema (Brasil). Las agresiones a mujeres también descendieron, pero no de forma significativa (Dualibi, Ponicki, Grube et al ,2007). En el Reino Unido las autorizaciones de venta de bebidas alcohólicas se liberalizaron en 2005 con el fin de prevenir la delincuencia y de reforzar la seguridad pública. Un estudio efectuado en un hospital, en el que se comparaban las urgencias antes y después de la nueva legislación sobre venta de bebidas alcohólicas, registró un incremento de las asistencias nocturnas relacionadas con el alcohol en urgencias. Asimismo, tras la introducción de las nuevas leyes, los pacientes resultaron más difíciles de tratar y exigieron más recursos, como exámenes más amplios y detallados. El cambio legisla-

\section{1.b Code of practice and other agreements}

The bar associations of different countries (Australia, UK, Sweden...) have adopted codes of practices, normally on a voluntary basis. This may be an important first step, implying that the industry accepts it has a role and a responsibility in the prevention of harm. This is quite a common practice in Australia, where much of the research has also been carried out. Unfortunately, however, assessment of the voluntary code of practice does not support its effectiveness (Graham, 2000; Wilkins and Sweetsur, 2009). Despite the existence of a Code of Practice for Responsible Promotion of Liquor Products in an Australian town, an 8-week follow-up clearly showed that there are numerous examples of promotions which breach both the spirit and the letter of the Code. It is equally evident that the system for monitoring compliance with the Code is fundamentally inadequate (Jones and Lynch, 2007).

But some experiences, in collaboration with the industry, and where the code of practice is mandatory, are promising (Lang and Rumbold, 1997; Wallin, 2005). An interesting document for consultation, produced by the British Home Office and the KPMG (2008), is the review of the 'Social Responsibility Standards for the Production and Sale of Alcoholic Drinks', launched in 2005. The five principles of good regulation would be: proportionality, accountability, consistency, transparency and targeting. The most effective schemes have their own specific structures, separate from the industry's institutions. But a code administered by a trade organisation, if properly structured and implemented, can be better than none at all. To be taken seriously, selfregulation demands adequate, meaningful and commercially significant sanctions for non-compliance.

\section{1.c Opening hours}

Restricting opening hours has been a traditional form of regulation in some countries, such as the UK. At peak times for alcohol-related offences, late trading is associated with higher BALs among those drinkers most at risk of alcoholrelated harm (Chikritzhs and Stockwell, 2007). Prohibition of alcohol sales after $11 \mathrm{pm}$ led to a reduction of almost 9 murders a month in Diadema (Brazil). Assaults against women also fell, but this effect was not significant. (Dualibi, Ponicki, Grube et al. (2007). The licensing laws in the United Kingdom were liberalised in 2005 with a view to preventing crime and enhancing public safety. An assessment carried out in a hospital comparing emergencies before and after the new licensing legislation found an increase in overnight alcohol-related ED attendances. Also, following the introduction of the new laws, the patients were more difficult to manage and required more resources, including more extensive and longer assessments. The legislative change has also been associated with an increase in alcoholrelated assaults and injuries and alcohol-related hospital 
tivo dio lugar a un incremento de las agresiones y las heridas relacionadas con el alcohol y de los ingresos hospitalarios (Newton, Sharker, Pahal, van den Bergh y Young, 2007).

Sin embargo, otro estudio demuestra que reducir las horas de apertura no influye en el número de visitas a las salas de urgencias por cuestiones relacionadas con el alcohol o por agresiones (Graham, McLeod y Steedman, 1998). En términos generales, según Graham (2000), no hay pruebas consistentes de que el ajuste de las horas de apertura de los locales sea una medida eficaz para reducir los problemas derivados de los bares. Pero una revisión de este mismo año (Stockwell y Chikritzhs, 2009) a partir de 49 estudios (14 de ellos cumpliendo todos los criterios) concluye que la ampliación de horarios si lleva a un aumento del consumo y de los problemas relacionados.

En la isla de lbiza -donde ciertas noches se reúnen más de 20.000 clientes de bares y discotecas-, algunas discotecas cerraban a las 6 a.m., y a esa hora abrian otras que permanecían abiertas todo el día, lo cual permitía a los clientes continuar con sus actividades sin parar durante 24 horas. Esta situación cambió hace unos años; en la actualidad todas las discotecas están cerradas unas horas por la mañana. Aún no se han valorado los resultados de esta decisión, pero seguramente es un paso en la dirección correcta.

\section{1. d Entorno físico y contextual}

Ciertos aspectos ambientales de los locales generan problemas, sin duda porque irritan o frustran a los clientes. Por ejemplo, la masificación y los tropezones (Macintyre y Homel, 1997), el humo del tabaco (Homel y Clark, 1994), la música a todo volumen y de mala calidad (Forsyth, 2009; Guéguen, Jacob, Le Guellec, Morineau y Lourel, 2008; Home y Clark, 1994), actividades como bailar o el billar (Graham, LaRocque, Yetman, Ross y Guistra,1980; Quigley et al., 2003), conducta sexual desinhibida o ambiente permisivo (Homel, Carvolth, Hauritz, Mcllwain y Teague, 2004; Graham et al., 2006).

Una forma de actuar sobre el ambiente de los locales es prohibir todo tipo de cristalería. En febrero de 2006 el Ayuntamiento de Glasgow promulgó una ordenanza municipal que prohibía utilizar vasos y copas en todos los locales con licencia para espectáculos del centro de la ciudad. En los establecimientos que utilizaban plástico había menor riesgo de lesiones que en los que seguían utilizando cristal. Los clientes reconocieron que se sentian más seguros en esas discotecas (Forsyth, 2008). En los lugares que utilizaban vasos y copas, el cristal "templado" con menor resistencia a los golpes provocó más lesiones, y por tanto habria que perfeccionar las técnicas de templado (Warburton, Shepherd, 2000).

Los locales que sirven comida registran menos violencia (Homel y Clark, 1994); tal vez porque atraen a una clientela distinta o porque la concentración de alcohol en sangre se altera.

El tipo de música influye en los clientes de las discotecas y en su comportamiento; por ejemplo, da lugar a diferencias en los niveles de alcohol o en el consumo de drogas ilegales, en la actividad sexual o en la violencia registrada en los admissions (Newton, Sharker, Pahal, van den Bergh \&t Young, 2007).

However, other research finds that restricting opening hours does not have an effect on the numbers of alcohol- or assault-related visits to emergency rooms (Graham, McLeod and Steedman, 1998). In general terms, according to Graham (2000), there is no strong evidence that adjusting hours of operation is an effective policy intervention for reducing bar-related problems. But, a more recent review (Stockwell y Chikritzhs, 2009) of 49 studies (14 included baseline and control measures) suggests that extended late-night trading hours lead to increased consumption and related harms.

On the relatively small island of Ibiza -where some nights there may be more than 20,000 clubbers around-, when some discos closed at 6 a.m., others were just opening, and remained open the whole day. This allowed clubbers to continue their activity non-stop, 24 hours a day. This situation changed a few years ago, so that there are now some hours in the morning during which all discos are closed. The outcomes of this decision have not yet been assessed, but this may be a step in the right direction.

\section{1. d Physical and contextenvironment}

There are environmental aspects of the venues that have proven to be related to different problems, possibly because they can cause frustration or irritation in patrons. Some examples are overcrowding and bumping (Macintyre and Homel, 1997), smokiness (Homel and Clark, 1994), bad and loud music (Forsyth, 2009; Guéguen, Jacob, Le Guellec, Morineau and Lourel, 2008; Home and Clark, 1994), activities such as dancing or pool (Graham, LaRocque, Yetman, Ross and Guistra,1980; Quigley et al., 2003), overt sexual activity or a permissive atmosphere (Homel, Carvolth, Hauritz, Mcllwain and Teague, 2004; Graham et al., 2006).

One example of addressing the venue's environment involves banning glassware. In February 2006, a Glasgow City Council bye-law was introduced banning glassware from all venues holding an Entertainment Licence within the city centre. Disorder in all-plastic venues was observed to incur less injury risk than others still using glass. Patrons also reported feeling safer in these nightclubs than in others (Forsyth, 2008). In cases where bars used glass, it seemed that "toughened" glass with lower impact resistance caused more injuries, so that standards for toughening need to be developed (Warburton, Shepherd, 2000).

Serving food is associated with less violence (Homel and Clark, 1994). This could be because such places attract a different clientele, or BAC is delayed.

Music policy was found to influence nightclubs' clientele and their behaviours, in relation, for example, to differences in levels of alcohol or illegal drug use, sexual activity and 
locales. Es aconsejable, por tanto, que la política musical se incorpore a los cursos de formación para el servicio responsable en los locales nocturnos (Forsyth, 2009).

El control del ruido es una cuestión de salud esencial. Una buena solución consiste en instalar limitadores de sonido en los amplificadores para no sobrepasar el nivel adecuado, pero la ley debe cumplirse. La rotación del personal contribuye a mitigar los daños causados por el ruido.

Las investigaciones sobre la densidad de los locales sostienen que las agresiones se relacionan estrechamente con la concentración de los mismos; es decir, a mayor densidad, mayores niveles de agresión. Con respecto a los accidentes de tráfico y la conducción bajo los efectos del alcohol, la evidencia de una relación lineal positiva es menos contundente (Chikritzhs, Catalano, Pascal y Henrickson, 2007). Asimismo, las agresiones en la calle guardan una estrecha relación con el número y capacidad de los locales (Warburton y Shepard, 2005).

\section{1.e. Análisis de pastillas in situ}

En el pasado el análisis de pastillas in situ era una medida habitual, aunque polémica, y se basaba en que la adulteración de pastillas era el principal problema. En la actualidad, ha perdido popularidad en Europa, e incluso en lugares pioneros como los Países Bajos ya no se utiliza este tipo de intervención in situ. Los principales argumentos contra el análisis de pastillas son la limitada capacidad de los análisis in situ para detectar de forma adecuada las sustancias dañinas, la desproporción entre costes/beneficios, y que los análisis de pastillas in situ generan mensajes contradictorios sobre los riesgos derivados del consumo y posesión de las sustancias controladas (EMCDDA, 2006). Por otro lado, la investigación no ha demostrado que la adulteración de las pastillas sea más dañina que las propias pastillas. Casi siempre, ocurre lo contrario, pues los problemas surgen más bien de la pureza de las sustancias.

\section{COMUNITARIAS O INTERVENCIONES MULTICOMPONENTES}

Son muchas las instancias interesadas en la regulación de la vida nocturna, y la cooperación entre ellas resulta fundamental. La prevención integral o multicomponente combina algunas o todas las siguientes intervenciones:

- Conciencia y movilización de la comunidad (colaboración y cooperación con sectores importantes, como las autoridades municipales, los pubs y las discotecas, los organizadores de fiestas, los servicios de salud/adicción y la policía).

- Formación: SRB, prevención de la violencia, personal de los locales (desde los porteros a los gerentes) y otros sectores interesados.

- Normas de la casa.

- Mejora de los niveles sanitarios y de seguridad de las zonas y locales nocturnos (entornos saludables). violence between venues. It is recommended that music policy be incorporated into responsible bar server training packages (Forsyth, 2009).

Noise control is an essential health issue. The installation of sound limiters linked to any sound amplification equipment at appropriate levels is a good solution, but the law must be enforced. Rotation of staff can also be very helpful for mitigating noise burden.

Outlet density research literature supports that assaults are highly correlated with outlet density; that is, as density increases so do levels of assault. In relation to studies on road accidents and drink-driving, the evidence for a positive linear relationship is less consistent (Chikritzhs, Catalano, Pascal and Henrickson, 2007). Also, street assault correlates significantly with numbers and capacity of premises (Warburton and Shepard, 2005).

\section{1.e. On-site pill-testing}

On-site pill-testing has in the past been quite a common but controversial measure, and was essentially based on the assumption that pill adulteration was the main problem. However, it is now becoming less popular in Europe, and even in pioneering countries such as the Netherlands this type of on-site intervention is no longer used. The main arguments against pill-testing are the limited capacity of on-site tests to accurately detect harmful substances, the poor costbenefit ratio, and the fact that allowing on-site pill-testing sends out contradictory messages about the risks related to both the use and possession of controlled substances (EMCDDA, 2006). Moreover, there is no research suggesting that adulteration of these pills is more harmful than the drug itself. Indeed, very often the contrary is true, with problems being related to the purity of the content.

\section{COMMUNITY OR MULTICOMPONENT INTERVENTIONS}

Many stakeholders are involved in the regulation of nightlife, and co-operation among them appears to be essential. An integral or multicomponent prevention approach combines some or all of the following interventions:

- Community awareness and community mobilisation (involvement of and cooperation with important stakeholders, such as municipal authorities, pubs and clubs, party organisers, health/addiction services, and police)

- Training: RBS, violence prevention, bar staff (from doormen to managers) and other stakeholders.

- House policies.

- Improving the health and safety levels of nightlife areas and venues (healthy settings). 
- Educación de los clientes para reducir los riesgos del consumo de drogas y alcohol.

- Cumplimiento de la ley.

Aunque sólo unos cuantos programas incluyen evaluaciones rigurosas con resultados claros, en general han demostrado su eficacia en la limitación del acceso de los jóvenes al alcohol, la reducción de pautas conflictivas de consumo de alcohol, los accidentes involuntarios con o sin vehículos y la violencia (Treno, Lee, Freisthler, Remer and Gruenewald, 2005). Algunas de las intervenciones estudiadas son:

- Community Trials Project o (Salinas, California). La intervención logró reducir la tasa de accidentes de tráfico nocturnos y los ingresos hospitalarios derivados de los mismos (Roeper, Voas, Padilla-Sánchez et al., 2000).

- The Surfers Paradise Safety Action Project, en la Costa Dorada de Queensland, Australia. Se produjo una notable reducción de la violencia y los delitos (dentro y fuera de los locales) y en las prácticas que fomentaban el consumo irresponsable de alcohol (como los incentives al consumo concentrado), así como mejoras en las medidas de seguridad, en los espectáculos, en el trato a los clientes y en las políticas de transporte (Homel, Hauritz, Wortly, Mcllwain y Carvolth, 1997).

- STAD (Stockholm Prevents Alcohol and Drug Problems). EI programa nació en 1996 y continúa funcionando con éxito. La principal intervención se basó en la movilización de la comunidad, la formación de los empleados de los locales en SRB y un cumplimiento más estricto de las leyes sobre el alcohol. Resultados: descenso de los problemas provocados por el alcohol en los establecimientos autorizados; aumento de los locales autorizados que se negaron a servir alcohol a clientes embriagados (del 5\% en 1996 al 47\% en 1999 y $70 \%$ en 2001); creciente rechazo a servir alcohol a menores (del 55\% en 1996 al 59\% en 1999 y $68 \%$ en 2001). Durante el período de evaluación del proyecto el número de agresiones descendió el $29 \%$ en la zona de ejecución del proyecto y experimentó un leve descenso en la zona de control (Wallin y Andréasson, 2005).

- Geelong Local Industry Accord (Lang y Rumbold, 1997). La intervención se basó en la colaboración entre la policía y los locales para reducir la violencia interpersonal. Se desarrolló un código de conducta escrito para contribuir a la autorregulación de los locales autorizados. Entre los resultados destaca la reducción de la violencia en un período de tres años.

La investigación indica que el enfoque comunitario es más eficaz que la ejecución de intervenciones aisladas (Holder, Gruenewald, Ponicki, Treno, Grube, Saltz et al., 2000; Wagenaar, Murray y Toomey, 2000). El problema de los proyectos comunitarios es conseguir la continuidad tras la fase inicial. A medio plazo surgen inconvenientes como el liderazgo, la participación de la comunidad o la financiación.
- Education for nightlife clients about reducing the risks of drug and alcohol use.

- Law enforcement.

While only a few such programs have included rigorous evaluations with well defined outcomes, these programs have generally proven to be effective in reducing young persons' access to alcohol, problematic drinking patterns, unintentional vehicular and non-vehicular injuries, and assaultive violence (Treno, Lee, Freisthler, Remer and Gruenewald, 2005). Some of the interventions evaluated are:

- Community Trials Project (Salinas, California). The intervention was successful in reducing the rate of nighttime traffic injuries and the number of admissions to hospitals due to traffic accidents (Roeper, Voas, PadillaSanchez et al., 2000).

- The Surfers Paradise Safety Action Project, in Queensland AUS's Gold Coast. Findings showed marked reductions in violence and crime (inside and outside venues) and in practices that promote the irresponsible use of alcohol (such as binge drinking incentives), as well as improvements in security practices, entertainment, handling of patrons, and transport policies (Homel, Hauritz, Wortly, Mcllwain and Carvolth, 1997).

- STAD (Stockholm Prevents Alcohol and Drug Problems). The program began in 1996 and still is implemented successfully. The main intervention included community mobilization, training of servers in RBS and stricter enforcement of existing alcohol laws. Results: a decrease in alcohol-related problems at licensed premises; an increase in licensed premises that refused alcohol to intoxicated patrons (from 5\% in 1996 to 47\% in 1999 and $70 \%$ in 2001); increased refusal to serve minors (from $55 \%$ in 1996 to 59\% in 1999 and 68\% in 2001). During the project evaluation period the number of assaults fell by $29 \%$ in the project area and slight increased in the control area (Wallin and Andréasson, 2005).

- Geelong Local Industry Accord (Lang and Rumbold, 1997). The intervention is based on collaboration between police and venues to reduce interpersonal violence. A written code of conduct was co-developed to assist self-regulation of licensed venues. Outcomes included a reduction of violence over a three-year period.

Scientific research indicates that a community approach will probably be more effective than the implementation of separate interventions (Holder, Gruenewald, Ponicki, Treno, Grube, Saltz et al., 2000; Wagenaar, Murray and Toomey, 2000). The problem with community projects is how to achieve their continuity after the initial phase. Leadership, community involvement or funding can be problems in the medium term. 


\section{EDUCATIVAS (EDUCACIÓN DE CLIENTES, EN LA ESCUELA, ENTRE IGUALES, ETC.) Y CAMPAÑAS}

La educación de los clientes (mediante folletos o utilizando el sistema de iguales...) es una intervención para la reducción de daños que se ha puesto en práctica a menudo en los ambientes recreativos. En las zonas de ocio se han repartido miles de folletos con información sobre reducción de daños (no conducir bajo los efectos del alcohol, beber agua cuando se consume MDMA -éxtasis-, etc.) Sin embargo, poco se sabe de su efecto para evitar el estado de intoxicación de los clientes o en la reducción de daños. Como medida aislada, su eficacia es muy reducida o inexistente si no se combina con la imposición de las leyes o con otros tipos de intervención (Graham, 2000).

Sin embargo, hay que tener en cuenta (Faggiano y Vigna-Taglianti, 2008) que las intervenciones de los medios de comunicación (mensajes breves y repetidos para informar y estimular a los individuos a abstenerse o reducir el consumo de sustancias) son a veces muy eficaces, sobre todo cuando se conjugan con acciones comunitarias. Es lo que ha ocurrido con el tabaco (despertando la conciencia, mejorando actitudes, reduciendo la prevalencia...), y en el caso del alcohol las campañas contra la conducción en estado de embriaguez han reducido los accidentes en un 10\% (Tay, 2005). Sin embargo, no existen estudios sobre las campañas contra las drogas ilegales.

Una idea que ofrece posibilidades interesantes es la que prevención en las escuelas que incluyan la prevención en ambientes recreativos nocturnos entre sus objetivos, puesto que es en dichos ambientes donde los jóvenes suelen consumir alcohol y drogas. En este contexto se necesitan habilidades especiales para tomar las decisiones más adecuadas.

La utilización de pares o iguales en intervenciones dentro de los ambientes recreativos ha gozado de gran popularidad, puesto que destaca la importancia de la edad del educador a la hora de ganarse la credibilidad de un determinado público. Por el mismo motivo se recurre a veces a jóvenes con experiencia en consumo de drogas. No obstante, no hay evaluaciones sobre el resultado de dichos programas. En los programas escolares, los pares o iguales resultan más eficaces que los profesores (Faggiano, 2008). Sin embargo, los programas que estimulan el contacto social corren el peligro de aumentar la exposición a influencias sociales negativas. No sólo los líderes, sino también los grupos tienen capacidad de reforzar las normas tanto positivas como negativas; $y$ por tanto, estas intervenciones deben ejecutarse con mucho cuidado (Philliber, 1999)

\section{SERVICIOS DE URGENCIAS, Y DE PRIMEROS AUXILIOS}

Durante las actividades recreativas surgen problemas médicos. En "ll love techno" (edición de 2001), una fiesta rave celebrada en un recinto cerrado a la que asistieron 37.000 personas, 0 "De Nacht», una tradicional fiesta de Noche-

\section{EDUCATION (PATRON EDUCATION, IN-SCHOOL EDUCATION, PEER-EDUCATION, ETC.) AND CAMPAIGNS)}

Patron education (through pamphlets, peer-to-peer approach...) has been a frequently-implemented form of harm-reduction intervention in recreational contexts. Thousands of pamphlets have been distributed in recreational areas with harm-reduction information (not to drive drunk, to drink water when using MDMA, etc.). However, there has been little assessment of their effect on patron's intoxication or on harm reduction. Their effectiveness as an isolated measure will probably be greatly reduced or nonexistent unless combined with enforcement or other types of intervention (Graham, 2000).

Nevertheless, we should consider (Faggiano and VignaTaglianti, 2008) that mass media interventions (brief and recurrent messages to inform and motivate individuals to abstain or reduce substance use) are sometimes a very effective measure, especially when they are implemented together with community actions. This has been seen in the case of tobacco (raising awareness, improving attitudes, reducing prevalence...), while in that of alcohol, drink-driving mass media campaigns have proven to reduce accidents by $10 \%$ (Tay, 2005). However, there are no assessments of campaigns against illegal drugs.

An idea with interesting possibilities would be for school prevention targeting adolescents to include recreational nightlife prevention among its objectives, since we know that this recreational context is where young people normally use alcohol and drugs. Special skills are needed to take the appropriate decisions in this context.

The use of peers in interventions in recreational settings has been quite popular, since it places the emphasis on the importance of the educator's age in establishing credibility with an audience. For the same reason, young people with experience of drug misuse are sometimes viewed as credible sources. Nevertheless, there are no outcome evaluations of such programs. In school programs, peers seem to be more effective than teachers (Faggiano, 2008). However, it should be borne in mind that programs which encourage social contact clearly run some risk of increasing the exposure to negative social influences. Not only the leaders, but also the groups have the potential for reinforcing both positive and negative norms, so that such interventions must be implemented with great care (Philliber, 1999)

\section{EMERGENCY ROOMS, MEDICAL AND FIRST AID SERVICES}

Medical problems related to recreational activities do occur. During 'I love techno' (2001 edition), an indoor rave party attended by 37,000 people, or 'De Nacht', a traditional New Year's Eve dance party, data on medical 
vieja, se recogieron datos sobre incidencias médicas (sobre todo, los problemas derivados de las drogas). La incidencia de problemas médicos en "l love techno" fue de 66,5/10.000 asistencias, y en el caso de "De Nacht" de 70,0/10.000 asistencias (Van Sassenbroeck, et al., 2003). La proporción de pacientes atendidos en los servicios de urgencias de los hospitales británicos por embriaguez fue del 4\% entre adultos; el $70 \%$ de los pacientes eran hombres, con una edad media de 30 años, y el 72\% ingresaron en urgencias entre las 20.00 y las 08.00 horas. El motivo más común para recibir asistencia fueron los accidentes (34\%), seguidos de cerca por las agresiones (30\%). El 27\% de los pacientes habian consumido gran parte del alcohol en casa, el $36 \%$ en un pub y el $16 \%$ en una discoteca (Benger y Carter, 2008).

El marcado descenso de las agresiones registradas en los locales autorizados a raíz de una serie de medidas dirigidas se reforzó con la intervención del servicio de urgencias y de especialistas maxilofaciales. Dos especialistas (uno de urgencias y un maxilofacial) visitaron los locales y mostraron detalles gráficos de las heridas sufridas, el tratamiento y el número de agresiones a los dueños de los locales. Asimismo, los informaron de que el servicio de urgencias llevaba un control sobre la violencia registrada en sus locales y que seis meses después se publicaría un informe que se daría a conocer en los medios de comunicación locales (Warburton y Shepard, 2005).

Cierto número de grandes discotecas tienen salas «médicas" para atender a esos individuos, pero no hay datos sobre esas intervenciones. Dada la falta de orientación concreta sobre la preparación del personal que trabaja en dichas salas, en algunos casos los clientes no han sido atendidos correctamente. Se ha elaborado una intervención para tratar este aspecto, consistente en un conjunto piloto de pautas y en una formación adecuada ; a partir de entonces, el personal médico de las discotecas tiene capacidad para diagnosticar a los clientes que sufren intoxicaciones por drogas recreativas, para utilizar las pautas y para llamar a una ambulancia en caso necesario (Wood, Greene, Alldus et al., 2008).

\section{CONTROL DE LICENCIAS, APLICACIÓN DE LA LEY Y CONTROL DE MENORES DE EDAD}

La mayoría de los estudios demuestran la eficacia de hacer cumplir las leyes y de la intervención policial. El primer ejemplo con resultado positivo es la introducción, en un centro turístico de la costa inglesa, de nuevas medidas de control y de supervisión de establecimientos de venta de bebidas en la zona portuaria, donde se concentran gran parte de los bares y las discotecas. Agentes de policía uniformados visitaron los bares entre 2 y 3 veces por semana, y los resultados mostraron una reducción del 20\% de los delitos por alteración del orden público en la zona de intervención, sin reducción en la zona de control (Jeffs y Saunders, 1983).

Las nuevas tecnologías juegan un papel importante en la seguridad nocturna. El Proyecto de Seguridad del Centro de la Ciudad de Manchester es una agencia puesta en marcha por la Policía del Gran Manchester. Adopta un criterio holis- problems (especially drug-related problems) were collected. The incidence of medical problems during 'I love techno' was 66.5/10,000 attendees, and in the case of 'De Nacht', 70.0/10,000 attendees (Van Sassenbroeck et al., 2003). The proportion of patients attending the Emergency Department in British hospitals as a result of alcohol intoxication was $4 \%$ in adults; $70 \%$ of patients were male, with a mean age of 30 years, and $72 \%$ attended the department between 20.00 and $08.00 \mathrm{~h}$. The most common reason for ED attendance was accidents (34\%), followed closely by assault (30\%). Twentyseven percent of patients had done most of their drinking at home, $36 \%$ in a pub and $16 \%$ in a nightclub (Benger and Carter, 2008).

Marked reductions in licensed premises assaults resulting from targeted policing were enhanced by the intervention of Emergency Department and maxillofacial consultants. Two consultants (ED and maxillofacial) visited these premises and presented in graphic detail the injuries sustained, treatment, and numbers of assaults to premises managers. They also informed the managers that the ED was auditing violence in their premises and that a report would be published six months later and disclosed to the local media (Warburton and Shepard, 2005)

A certain proportion of big clubs have 'club medic' rooms for managing these individuals, but there have been no evaluations of such interventions. Due to the lack of specific guidance on the training of staff working in these rooms, there have been instances where clubbers have been inappropriately managed within the club environment. One intervention has addressed this issue by developing a pilot set of guidelines and implementing appropriate training; after this, all the club medic staff were confident in their ability to assess unwell clubbers with recreational drug toxicity, to use the guidelines and to know when to call an ambulance (Wood, Greene, Alldus et al., 2008).

\section{LICENSING, LAW ENFORCEMENT AND UNDE- RAGE CONTROL}

Most of the research supports the efficacy of law enforcement and police intervention. A first successful example has been the introduction, in an English seaside resort, of new policing practice with regard to the supervision of licensed premises in the harbourside area, where there is the greatest concentration of public houses and licensed clubs. Uniformed police officers visit pubs 2 to 3 times a week, and the results showed a $20 \%$ of reduction in recorded public disorders offences in the intervention area, with no reduction in the control area (Jeffs and Saunders, 1983).

New technologies play an important role in night-time safety. Manchester City Centre Safe Project is an agency run by Greater Manchester Police. It adopts a holistic and long-term approach to reducing alcohol-related crime in 
tico y a largo plazo para reducir los delitos relacionados con el alcohol en el centro de la ciudad. Abarca veinte iniciativas independientes que abordan diferentes aspectos del problema. Por ejemplo, colaboró en la introducción del sistema de radio "Nite Net" que pone en comunicación pubs, discotecas, un circuito cerrado de televisión y a los agentes de policía durante la noche. De ese modo pueden enviar información sobre clientes agresivos expulsados de los locales y dirigir a la policia hacia grupos concretos de alborotadores (Roberts, 2004). Las medidas de vigilancia en los pubs han florecido en tiempos recientes en el Reino Unido. La Ley de Permiso de Venta de Bebidas Alcohólicas de 2003 recomienda a todos los establecimientos contar con un proyecto de "vigilancia». Más de las tres cuartas partes de los participantes (77,5\%) en la encuesta nacional expresaron la intención de aplicar las medidas de vigilancia de los pubs a sus zonas estableciendo comunicación directa con los centros de control por circuitos cerrados de TV (CCTV) de la policía. En conjunto, hay pruebas que indican que estas medidas ejercen un efecto positivo en la reducción de los delitos, aunque dicha reducción es bastante pequeña si se considera el número total de delitos. La evidencia demuestra que el CCTV es más eficaz para reducir los delitos contra la propiedad que contra las personas (Brown, 1995).

Llama la atención que, a pesar de que la coerción ha demostrado ser una intervención eficaz, hay cierta resistencia a ejecutar medidas de ese tipo. Los motivos son numerosos: ignorancia de la ley o ideas equivocadas sobre la misma, desconocimiento de los efectos del alcohol, incapacidad para valorar el daño del alcohol, sobre todo si, como suele ocurrir, el propio agente de policia también bebe (Jeffs y Saunders, 83). Las discotecas son negocios, y a Homel (2004) le preocupan los tratos secretos tan propios de este tipo de industria: "la policía y los funcionarios que expiden las autorizaciones para venta de bebidas no se ocupan de los locales si no hay problemas graves que atraigan la atención de los medios de comunicación o de los políticosı.

La policía tiene capacidad para jugar un papel de liderazgo en la reducción de los incidentes y los daños provocados por el alcohol. Es más fácil mantener un buen ambiente cuando se cuenta con apoyo político y se centra el interés en actividades para reducir el daño derivado del alcohol. Sin embargo, hay que conseguir el compromiso de los representantes locales y la cooperación de un centro local que coordine los recursos físicos y humanos disponibles (Doherty y Roche, 2003).

El consumo de alcohol entre menores de edad es un problema importante, sobre todo en Europa, donde la edad legal para comprar alcohol baja en algunos casos de los 18 años. Hay pocos estudios sobre los efectos hacer cumplir la ley, pero los que hay demuestran que dicha imposición reduce la venta de bebidas a los jóvenes. Por ejemplo, la relación de controles evitan la venta de alcohol a menores, pero los efectos disminuyen con el tiempo, lo cual indica la necesidad de un programa sostenido para mantener la disuasión (Wagenaar, Toomey y Erickson, 2005). Los aparatos de verificación electrónica de la edad (VEE) son uno de los medios para reducir las ventas de tabaco y bebidas alcohólicas a the city centre. It comprises twenty separate initiatives that tackle different parts of the problem. For example, it was involved in introducing the 'Nite Net' radio system that links pub, clubs, CCTV and police officers together in the night-time hours. They can then warn each other of aggressive customers who have been ejected from venues and can target police activity towards particular groups of troublemakers (Roberts, 2004). Pub watch and club watch schemes have flourished in recent years in the UK. The Licensing Act 2003 recommends that all premises subscribe to a 'watch' scheme. Over three-quarters of the respondents $(77.5 \%)$ in the national survey expressed an intention to extend the pubwatch schemes in their areas with direct links to police CCTV control centres. On the whole there is evidence to suggest that these schemes have a significant desirable effect on crime reduction, though such reduction may be rather small across all crimes. Evidence suggests that CCTV is more effective in reducing crimes against property than crimes against the person (Brown, 1995).

What is striking is that despite the fact that enforcement has proved to be an effective type of intervention, there is some reluctance to implement such kinds of policies. Many reasons can be suggested: ignorance of, or mistaken beliefs about the law, a lack of knowledge about the effects of drink, and a failure to see much harm in drinking, especially if, as is often the case, the police officer is a drinker him/ herself (Jeffs and Saunders, 83). Nightclubs are businesses, and Homel (2004) is worried about the hidden deals that are so characteristic of this industry: "venues will be left alone by police and licensing officials if there is no trouble serious enough to attract media or political attention".

It has been shown that police have the ability to play a leadership role in reducing alcohol-related incidents and harm. Sustained success is more likely when there is political support for and focus on alcohol-related harmreduction activities. However, responses must engage local representatives and involve a local focus sensitive to available physical and human resources (Doherty and Roche, 2003).

Underage drinking is a substantial problem, especially in Europe, where the legal age for buying alcohol may be even lower than 18. Studies of enforcement effects are few, but results show that enforcement can reduce sales to youth. For example, enforcement checks prevent alcohol sales to minors, but effects can diminish over time, suggesting that a regular schedule of enforcement is necessary for maintaining deterrence (Wagenaar, Toomey and Erickson, 2005). Electronic Age Verification (EAV) devices are one means of reducing underage sales of tobacco and alcoholic beverages, and thus avoiding the fines and license suspensions/ revocations which can result from non-compliance. EAV devices - using similar technology to credit and ATM card scanners- read the date of birth encoded on the magnetic strip and/or bar code on the back of the customer's driver's 
menores, gracias a los cuales se evitan las multas y las suspensiones/revocaciones de los permisos en caso de incumplimiento. Los aparatos de VEE utilizan tecnología similar a los escáneres de los cajeros automáticos, leen la fecha de nacimiento codificada en la banda magnética o en el código de barras del carnet de conducir del cliente o en un documento de identidad similar y calculan si el posesor de la tarjeta tiene la edad reglamentaria para comprar tabaco o bebidas alcohólicas. Aunque los VEE contribuyen a una estimación más ajustada de la edad, no incrementaron la verificación de la edad en un experimento en el que su utilización era voluntaria (Krevor, Capitman, Oblak et al., 2003).

\section{CONTEXTOS, AMBIENTES, VECINDARIO (TRANSPORTE, ILUMINACIÓN...)}

Los problemas no se reducen al interior de los locales. En realidad, gran parte de la violencia se produce fuera de los mismos y tiene que ver con cuestiones ambientales externas. Son varios los factores que pueden desencadenar problemas:

- Las colas en las paradas de taxis o autobuses provocan a veces discusiones y peleas (Allen y Goody, 2002).

- Falta de transporte público (Homel et al., 2004; Marsh y Kibby, 1992).

- Gente que merodea fuera de los locales a la hora de cierre (Marsh y Kibby, 1992; Graham, Bernards, Osgood y Wells, 2006).

- Densidad de los establecimientos (Homel et al., 1997; Zhu, Gorman y Horel, 2004).

- Gran número de personas embriagadas concentradas en un punto y compitiendo por comida y medios de transporte limitados (Marsh y Kibby, 1992)

La solución a todas estas cuestiones es esencial para garantizar la seguridad y erradicar la violencia.

En Leeds, por ejemplo, las paradas de taxis y autobuses se han dispersado para evitar grandes concentraciones de gente. En Manchester la policía vigila estrechamente las colas en las paradas de taxis y buses (Robert, 2004).

En muchas ciudades se han introducido autobuses nocturnos y otros servicios de transporte. La existencia de aparcamientos también es muy útil, aunque el uso de los coches particulares se asocia a la conducción bajo los efectos del alcohol.

La iluminación y los teléfonos públicos también contribuyen a proporcionar un ambiente seguro.

El problema de controlar el ruido de los clientes que salen de los establecimientos autorizados una vez abandonan la zona inmediata a los locales no es fácil de solucionar. Entre las sugerencias se cuentan las campañas educativas, las advertencias y avisos dentro de los locales por medio de carteles y de la intervención directa del personal de puertas (MCM Research, 2003). license or similar ID and then calculate and display whether the card-holder is old enough to purchase tobacco or alcohol products. Although EAVs may have improved the accuracy of age verification, they did not increase the frequency of age verification in an experiment in which their use was on a voluntary basis (Krevor, Capitman, Oblak et al., 2003).

\section{ENVIRONMENTS, NEIGHBOURHOOD (TRANS- PORT, LIGHTING...)}

Problems are not only related to inside venues. In fact, a good deal of violence takes place outside venues, and is related to external environmental factors. Problems can be triggered by various factors:

- queuing for taxis or buses can trigger arguments and fights (Allen and Goody, 2002)

- lack of availability of public transport (Homel et al., 2004; Marsh and Kibby, 1992).

- people hanging around outside the bar at closing time (Marsh and Kibby, 1992; Graham, Bernards. Osgood and Wells, 2006).

- outlet density (Homel et al., 1997; Zhu, Gorman and Horel, 2004).

- large numbers of intoxicated people congregating and competing for limited food and transport facilities (Marsh and Kibby, 1992)

The solution to all these questions is essential to ensure safety and avoid violence.

In Leeds, for example, taxi ranks and bus stops have been dispersed to avoid large concentrations of people. In Manchester the queues for taxi ranks and buses are especially closely policed (Robert, 2004).

Late-night buses and other transport facilities have been introduced in many towns. The provision of parking areas is also very useful, but the use of private cars is associated with drinking and driving.

Lighting and telephone facilities are also useful for providing a safe atmosphere

The problem of controlling noise from customers leaving licensed premises once they have left the immediate vicinity of the venue itself is not easily solved. Suggestions include educational campaigns, and advice and reminders within the premises by means of posters and the direct intervention of door staff (MCM Research, 2003). 


\section{PROGRAMAS SOBRE LA CONDUCCIÓN BAJO LOS EFECTOS DEL ALCOHOL}

Conducir en estado de embriaguez o tras consumir drogas es una cuestión cada vez más preocupante. Se ha observado que los clientes de discotecas y similares utilizan muy a menudo su propio coche $(37,5 \%)$ para desplazarse hasta las zonas de ocio (Calafat et al., 2009). La Organización Mundial de la Salud calcula que, en los paises europeos, el alcohol es responsable del $45 \%$ de las incapacidades provocadas por los accidentes de tráfico entre los hombres y del 18\% entre las mujeres (López, Mathers, Ezzati, Jamison y Murray, 2006).

Una de las intervenciones más populares es la del conductor designado. Se trata de una medida que tiene todo el apoyo de la industria recreativa. En algunos casos la propia industria participa activamente, fomentando el programa de conductores designados con incentivos como consumiciones gratis. En Europa hay pocos estudios sobre los programas de conductores designados, pero la limitada información con que se cuenta acerca de la eficacia de dichos programas indica, lamentablemente, que son menos eficaces para prevenir la conducción bajo los efectos del alcohol de lo que se pensó en un principio. Hasta el momento la evidencia apenas avala la validez de los programas de conductores designados para reducir la conducción bajo los efectos del alcohol (Aresi, Fornari, Repetto y Scolari, 2009; Eurocare, 2003). Hay que tener en cuenta, además, que las acciones peligrosas de los pasajeros embriagados estresan al conductor y fomentan a veces situaciones de conducción de alto riesgo, imposibilitando la conducción segura (Rothe y Carroll, 2009).

El estado de Oregón impuso la formación obligatoria de todas las personas que sirven bebidas alcohólicas y de los propietarios/gerentes de los locales. Se registraron reducciones significativas de los accidentes de tráfico nocturnos en vehículos con un solo ocupante (vinculados a altos porcentajes de alcohol) (Holder y Wagenaar, 1994).

Intervenciones más clásicas, como los controles de alcohol en sangre o el aumento de la edad mínima para consumir alcohol, son herramientas de gran importancia para controlar este problema. Los programas obligatorios de control de alcoholemia han contribuido a una reducción significativa del papel del alcohol en los accidentes de tráfico mortales (Brady, Baker, Dimaggio, McCarthy, Rebok y Li, 2009). La legislación que establece la edad mínima para consumir alcohol en 21 años en Estados Unidos es una de las medidas de salud pública más eficaces que se han adoptado en época reciente, y entre sus efectos se incluye la prevención de la conducción bajo los efectos del alcohol de quienes no alcanzan la edad legal (Fell, Fisher, Voas, Blackman y Tippetts, 2007).

También se ha estudiado la eficacia de los dispositivos antiarranque para evitar que un conductor embriagado conduzca. Este tipo de intervención, utilizada con personas con antecedentes de conducción bajo los efectos del alcohol, mostró buenos resultados durante el tiempo que se utilizó el dispositivo antiarranque, pero la eficacia desapareció cuando se retiró dicho dispositivo (Willis, Lybrand y Bellany, 2004).

\section{DRINK-DRIVING PROGRAMMES}

Driving while drunk or after using drugs is of widespread concern. It has been found that clubbers use their private car quite often (37.5\%) to get to recreational areas (Calafat et al., 2009). The World Health Organization estimates that in European countries, alcohol is responsible for 45 percent of the burden of disability arising from motor vehicle accidents for men and for 18 percent of the burden for women (Lopez, Mathers, Ezzati, Jamison and Murray, 2006).

One of the most popular interventions is that of the designated driver. This is a measure strongly supported by the recreational industry. In some cases the industry participates actively, backing the designated driver program by offering free drinks or other incentives. In Europe, there has been little assessment of designated driver programs, but the limited information that is available on the effectiveness of such programs suggests, unfortunately, that these programs are less effective in preventing alcohol-impaired driving than originally envisaged. There is little evidence to date that designated driver programs lead to a reduction in drinking and driving (Aresi, Fornari, Repetto and Scolari, 2009; Eurocare, 2003). It should also be taken into account that the unsafe actions of drunken passengers in the vehicle creates stress for the driver that can lead to high-risk driving situations and the disruption of safe driving (Rothe and Carroll, 2009).

The state of Oregon introduced compulsory training for all alcohol servers and owners/managers. Statistically significant reductions were found in single-vehicle nighttime traffic accidents (those with high percentages of alcohol involvement) (Holder and Wagenaar, 1994).

More classical types of intervention, such as blood alcohol controls or increasing the minimum legal age for drinking, are highly important tools for controlling this problem. Mandatory alcohol testing programs may have contributed to a significant reduction in alcohol involvement in fatal motor carrier crashes (Brady, Baker, Dimaggio, McCarthy, Rebok and $L i, 2009$ ). The legislation setting the minimum legal drinking age at 21 in the United States has been documented as one of the most effective public health measures adopted in recent times, its effects including the prevention of alcohol-impaired driving by those under the legal age (Fell, Fisher, Voas, Blackman and Tippetts, 2007).

The effectiveness of placing interlocks on the ignition to prevent an alcohol-impaired driver from operating the car has also been assessed. Assessment of this type of intervention, used with drink-driving offenders, showed good results during the period of time they were using the interlock, but the effects disappeared when the interlock was removed (Willis, Lybrand and Bellany, 2004). 


\section{IMPLEMENTACIÓN DE POLÍTICAS. COLABORA- CIÓN CON LA INDUSTRIA}

Como hemos mostrado anteriormente, las normas voluntarias de la industria son normalmente ineficaces, aunque se pueden considerar como un primer paso hacia un compromiso más profundo por parte del sector. En varios países europeos se ha ensayado la colaboración entre la industria del ocio y las autoridades locales; es el caso del Reino Unido, Países Bajos, Alemania, Bélgica, Suecia, República Checa, Italia, Francia o Lituania, en muchos casos siguiendo el modelo británico del "safer dance" (EMCDDA, 2009). Las posibilidades de colaboración son numerosas: formación del personal, colaboración con la policía y con los servicios de urgencias, puesta en práctica de campañas de conductores designados, etc.

Dicha colaboración se facilita cuando es obligatoria 0 cuando la opinión pública exige soluciones a determinados problemas. Los profesionales de la prevención consideran esencial un verdadero compromiso de la industria del ocio. A pesar del claro crecimiento de los problemas entre los asiduos de fiestas en los países europeos, se han registrado menos respuestas en 2007 que en 2004 (EMCDDA, 2009).

La industria de bebidas alcohólicas de la UE ha puesto en práctica algunas iniciativas voluntarias para reducir el daño provocado por el alcohol (ejemplos de dichas iniciativas se pueden ver en páginas web como www.europeanspirits. org, www.efrd.org, o www.drinkaware.co.uk). A la industria le preocupa mucho la posible imposición de una legislación más restrictiva, por eso les interesa demostrar su disposición a cooperar. Sin embargo, apoya medidas como los programas de conductores designados o las normas de cumplimiento voluntario que no tienen el aval de la investigación, y en cambio no apoya otras medidas que han demostrado su eficacia, como el aumento de los impuestos. La realidad es que actualmente acceder a las bebidas alcohólicas es más asequible en todos los paises de la UE (excepto Italia) desde 1996 (Rabinovich, Brutscher, de Vries, Tiessen, Clift y Reding, 2008).

Toda buena iniciativa para prevenir problemas en los ambientes recreativos exige que la policía, las autoridades locales y otros sectores interesados ofrezcan pruebas estadisticas para realizar una valoración formal del efecto acumulativo de los problemas de delincuencia, alborotos y perturbaciones del orden público. Asimismo, debería consultarse a todas las partes interesadas (DCMS, 2004).

Las buenas políticas dentro de un distrito de ocio comienza con la planificación del distrito y el diseño del entorno. Los principales problemas son la concentración de discotecas y bares, y una disposición inadecuada de calles, aceras y aparcamientos. Las medidas esenciales desde una perspectiva proactiva son: identificar a los posibles alborotadores, realizar inspecciones en los bares, evitar las concentraciones de gente, descongestionar los lugares recargados, garantizar la circulación de los peatones y cortar de raíz las actividades de las bandas (Berkley y Thayer, 2000).

\section{POLICING; COLLABORATION WITH THE INDUSTRY}

We have already mentioned that voluntary industry codes of practiques are generaly ineffective, even though they can be considered as a first step towards more effective commitment from the industry. Collaboration between the leisure industry and local authorities has been set up various European countries, such as the UK, the Netherlands, Germany, Belgium, Sweden, the Czech Republic, Italy, Germany, France or Lithuania, sometimes based on the UK's 'safer dance' guidelines (EMCDDA, 2009). There are many possibilities for collaboration: staff training, cooperation with police or emergency departments, implementing designated driver campaigns, and so on.

Such collaboration is facilitated when it is mandatory or when there is strong public opinion demanding solutions as a consequence of some problems. Prevention professionals believe that the real involvement of the leisure industry is essential. In spite of an admitted growth in the incidence of partygoer problems in European countries, there were fewer assessed responses in 2007 than in 2004 (EMCDDA, 2009).

There are some voluntary initiatives by the EU spirits industry to help reduce alcohol-related harm (some examples of these initiatives can be seen on web pages such as www.europeanspirits.org, www.efrd.org, or www. drinkaware.co.uk). There is strong concern in the alcohol industry over the possibility of more restrictive legislation, and that is why they are interested in demonstrating that they are cooperating. However, they support measures such as designated driver programmes or volunteer codes of practice that are not supported by research, and fail to support measures that have shown their efficacy, such as increasing taxation. The fact is that the affordability of alcohol has increased in all EU countries (apart from Italy) since 1996 (Rabinovich, Brutscher, de Vries, Tiessen, Clift and Reding, 2008).

A good policy approach to the prevention of problems in the recreational context requires the police, local authority and other interested parties to provide statistical evidence in order to make a formal assessment of the cumulative effect of problems of crime, disorder and public nuisance within a specified boundary. It should also be informed by consultation with the relevant stakeholders (DCMS, 2004).

Effective entertainment-district policing begins at the district planning and design stage. Concentrations of nightclubs and bars, and inadequate street,parking, and sidewalk capacities are the main problems. Identifying potential troublemakers, making proactive bar checks, preventing congregations, cooling hot spots, assuring pedestrian flow, and stopping gang activity are the main forms of proactive policing (Berkley and Thayer, 2000). 


\section{PROGRAMAS ALTERNATIVOS}

Carmona y Stewart (1996) estudiaron la eficacia de las medidas alternativas para el Centro para la Prevención del Abuso de Sustancias (CSAP). Definieron como actividades "alternativas" los programas y eventos que excluian el alcohol, el tabaco y las drogas y en los cuales la participación era voluntaria. Hubo muchas variantes, y sus componentes incluian casi siempre la transmisión de conocimientos y actitudes, la capacitación de destrezas, actividades prosociales y sin estructurar, la relación con iguales y el desarrollo de relaciones positivas con adultos o la supervisión a cargo de adultos. Identificaron sólo 10 estudios con una Metodología que les permitió clasificarlos de relativamente concluyentes. Hay escasa evidencia de la eficacia de dichas medidas.

En España la mayoría de las ciudades organizan actividades alternativas las noches de los fines de semana (como talleres o la apertura de espacios públicos para practicar deporte), paralelas a las actividades nocturnas habituales con la pretensión de ejercer un efecto preventivo. La valoración de uno de estos programas alternativos no mostró ninguna influencia en el consumo de drogas o en el cambio de actitudes/conductas con relación al grupo de control (Fernández-Hermida y Secades, 2003). El problema de estos programas es que a veces incluso son contrarios a la prevención, puesto que admiten a preadolescentes y no evitan que la gente acuda posteriormente a los locales de ocio nocturno habituales.

Hay más estudios sobre este tipo de programas alternativos, pero debe tenerse en cuenta que la mayoría de ellos no se refieren a la prevención de los problemas relacionados con el alcohol y las drogas entre los clientes de los locales de ocio nocturno. Según un análisis de programas realizado por Norman (1997), no hay pruebas de que organizar actividades artísticas, deportivas y de ocio... contribuya a reducir el consumo de drogas. En un estudio de 45 programas contrastados de diferentes tipos (Hansen 1992), casi todos arrojaron resultados positivos, con la excepción de los programas que ofrecian experiencias alternativas (experiencias incompatibles con el consumo de sustancias).

\section{ENFOQUES CULTURALES}

Salir de noche los fines de semana es un fenómeno muy complejo que ha crecido de forma incesante en las últimas décadas. Muchos jóvenes participan activamente en este contexto, controlado básicamente por la industria del ocio. Este nuevo modelo de diversión es hegemónico para muchos jóvenes, es decir, excluye otras formas de ocio. Por otro lado, cumple muchas funciones: socialización, la búsqueda de amigos, opciones sexuales, etc. En este contexto, para quienes consumen drogas cada sustancia ocupa un lugar concreto dentro de las preferencias y objetivos de cada cual. El éxtasis se asocia con el baile, el alcohol con la desinhibición y la sociabilidad, y así sucesivamente. Es obvio que los más asiduos de este tipo de diversión son más propensos al consumo y el abuso del alcohol y las drogas (Calafat, 2004). Measham

\section{ALTERNATIVE PROGRAMS}

Carmona and Stewart (1996) reviewed the effectiveness of alternative approaches for the Centre for Substance Abuse Prevention (CSAP). They defined as 'alternative' activities, programmes and events at which alcohol, tobacco and drugs were excluded and in which participation was voluntary. These took many different forms, and their components frequently included the transmission of knowledge and attitudes as well as skills training, use of free and otherwise unstructured time, pro-social activities, interaction with pro-social peers and development of positive relationships with adults or supervision by adults. They could identify only 10 studies with a methodology allowing them to be classed as relatively conclusive. There is little evidence for the effectiveness of these measures.

In Spain, many towns organise alternative activities on weekend evenings (such as workshops, or opening up public places for sport), in parallel to the usual nightlife activities, aimed at having a preventive effect. An assessment of one of these alternative programs showed no effects on use of drugs or change of attitudes/behaviors in relation to the control group (Fernández-Hermida and Secades, 2003). The problem with such programs is that they can even be counter-preventive, since they are open to preadolescents and do not prevent people attending the usual nightlife venues later.

There are some other reviews of this type of alternative program, but it should be borne in mind that most of these reviews do not actually refer to the prevention of alcoholor drug-related problems in people attending nightlife venues. According to a review of programmes by Norman (1997), there is no evidence that organising artistic, sports or other types of alternative leisure activities will be, in itself, successful in reducing the use of drugs. In a review of 45 assessed programs of different types (Hansen 1992), nearly all of them yielded positive results, with the exception of the programs that provided alternative experiences (experiences incompatible with the use of substances).

\section{CULTURAL APPROACHES}

Going out on weekend nights is a highly complex phenomenon that has been growing steadily over recent decades. Many young people participate actively in this event, which is basically managed by the recreational industry. This new model of fun tends to become hegemonic for many young people, i.e., excluding other forms of entertainment. On the other hand, it performs many functions: socialization release, seeking a mate, sexual choices, and so on. Within this context, and for those who use drugs, each specific substance has its place within the preferences and objectives of each person. Ecstasy is associated with better dancing, alcohol with disinhibition and sociability, and so on. Obviously, those most strongly involved in this model of fun are more likely to use and abuse 
y Hadfield (2009) ofrecen más información sobre esta cultura de discoteca dentro de los ambientes del ocio nocturno.

La prevención de conductas de riesgo en estos contextos no es sencilla, puesto que existe un complejo marco cultural y económico que confiere significado a todo. Cuesta creer que se vayan a producir cambios significativos en la presente situación sin introducir cambios reales en el simbolismo, alcance y expresión de esta cultura y de la economía que la sustenta. La verdad es que, en términos generales, no se ha cuestionado seriamente la cultura recreativa; no lo ha hecho la sociedad en general ni las líneas políticas y los programas de prevención actuales. En algunos casos ha ocurrido todo lo contrario. En concreto, las intervenciones basadas principalmente en ofrecer información a quienes asisten a las fiestas (muy común en Europa) o en el análisis de pastillas parten de un respeto absoluto hacia la actual racionalidad del ocio y se conforman con transmitir a los consumidores de drogas la información y las habilidades necesarias para reducir los riesgos derivados de sus conductas recreativas.

Pero es difícil mantener esta "neutralidad". La propaganda de las discotecas y la forma en que se anima o disuade a los posibles clientes son claros ejemplos del efecto de esos procesos informales en la selección de élites; grandes proporciones de jóvenes son excluidos de dichos espacios, bien directamente, prohibiéndoseles la entrada, o indirectamente, haciendo que se sientan incómodos o fuera de lugar (Measham, 2009). Las relaciones sociales son un aspecto esencial para muchos jóvenes profesionales. Un estudio sobre profesionales británicos entre 25 y 34 años demostró que las relaciones sociales eran el aspecto más importante de sus vidas. Casi la mitad consideraban el trabajo importante, pero no fundamental, y sólo el $16 \%$ daban prioridad absoluta a sus carreras profesionales. La tendencia era más pronunciada entre las mujeres: el 40\% desmintieron el estereotipo de la mujer volcada en su carrera y afirmaron que la principal función del trabajo era tener una gran vida social (Goswami, 2004).

La cultura del ocio nocturno influye mucho en las categorias que los jóvenes elaboran sobre el placer, la diversión, las relaciones sociales, el consumo de alcohol y drogas, etc. Los programas y las políticas tradicionales de prevención poco influyen en esta cultura. Pero los enfoques ambientales son medidas de prevención que funcionan a la altura de esas normas sociales y culturales. En ese sentido, cobran importancia las reglas, la normalidad y los valores sobre el consumo de sustancias. Pero no sabemos gran cosa sobre el funcionamiento de dichos factores $y$, en consecuencia, no hay muchas intervenciones basadas en ellos. En un estudio para observar si la intervención por retroalimentación o feedback de normas sociales reduce el consumo excesivo de alcohol entre estudiantes universitarios, se obtuvieron resultados positivos con el feedback por ordenador/web (WF) y con el feedback cara a cara (IFF). Este tipo de intervenciones pueden ser eficaces para reducir el consumo excesivo de alcohol. No se hicieron comparaciones directas entre el WF y el IFF, pero el WF ofreció un conjunto más amplio de resultados y es menos costoso; por tanto, resulta preferible. Los efectos significativos se notaron más a corto plazo (hasta alcohol and drugs (Calafat, 2004). More information about these club cultures in the night-life scene can be found in Measham and Hadfield (2009).

Thus, preventing risk behaviors in these contexts cannot be a simple matter, as there is a complex cultural and economic framework that gives meaning to everything. It seems difficult to imagine that there can be significant changes in the present situation without introducing real changes in the symbolism, extent and expression of this culture and its supporting economy. The truth, however, is that in general terms there has been no genuine questioning of this recreational culture, either by society in general or in current policies and prevention programmes. Indeed, quite the opposite is true in some cases. In particular, interventions based mainly on giving information to the partygoers (very common in Europe) or on pill-testing are based on a strict respect for the actual recreational rationality, and only attempt to convey to drug users the information and abilities necessary to reduce the risk associated with their recreational behaviour.

But this 'neutrality' is difficult to sustain. The promotion of club nights and the ways in which potential customers are encouraged or discouraged from entering are clear examples of how these informal processes have an effect on the selection of clubbing elites; thus, large proportions of young people are excluded from such spaces, either directly, through being denied entry, or indirectly, by being made to feel uncomfortable or unworthy (Measham, 2009). Socialising has become a central aspect for many young professionals. Research carried out on 25 to 34-year-old British professionals found that socialising was the most important aspect of their lives. Almost half saw work as significant but not dominant, with only $16 \%$ putting careers as their top priority. The report found that the trend was most pronounced among women, with 40\% defying the career-girl stereotype and saying the main function of work was to fund a busy social life (Goswami, 2004).

Nightlife culture has a strong influence on the way young people categorize pleasure, entertainment, social relations, alcohol and drug use, and so on. Obviously, traditional prevention programs or policies are highly unlikely to influence this culture. However, environmental approaches are prevention measures that operate at the level of these social and cultural norms. In this sense, norms, normality and values regarding substance abuse are an important issue. But we do not know much about how such factors operate, and, consequently there are not many interventions addressing them. In a review of the research to determine whether social norms feedback intervention reduces alcohol misuse in university or college students, there were positive outcomes for Web/computer feedback (WF) and individual face-toface feedback (IFF). These sorts of intervention are probably effective in reducing alcohol misuse. No direct comparisons of WF with IFF were found, but WF impacted across a broader set of outcomes and is less costly, so that it could be preferable. Significant effects were more apparent for short-term outcomes (up to three months). For mailed and group feedback, and for social norms marketing campaigns, 
tres meses). En el caso del feedback por correo o en grupo y de las campañas de promoción de normas sociales, los resultados no son significativos, y por tanto dichas alternativas no se recomiendan (Moreira, Smith y Foxcroft, 2009).

En resumen, el aspecto cultural es esencial. Sin embargo, hacen falta estudios bien orientados que describan y analicen los elementos culturales dentro de su realidad social para saber qué tipo de intervención conviene poner en práctica. Una cuestión básica de este punto es la gran importancia de la ideología. Las intervenciones dirigidas a los principios culturales y recreativos no dependerán sólo de la voluntad o las habilidades de los profesionales, sino más bien de cambios de la sociedad en conjunto.

\section{MEDIDAS DE PREVENCIÓN "CLÁSICAS»}

La base del presente estudio no contempla el análisis de la eficacia de las medidas clásicas, aunque se ha aludido a ellas al analizar otras intervenciones relacionadas de forma más directa con los ambientes de ocio nocturno. Las intervenciones clásicas se centran fundamentalmente en la reducción del daño provocado por el alcohol, pero entendemos que este tipo de intervención también influye en los problemas derivados del ocio nocturno.

Se ofrece a continuación una breve lista de dichas intervenciones (Giesbrecht, 2008) :

- Aumento del precio real de las bebidas alcohólicas e interrupción de los descuentos y las rebajas.

- Establecimiento de un techo y un límite para otros factores: horarios y días de venta, densidad de establecimientos en cuyo interior se consume y aquellos que venden para consumir fuera.

- Renovación de la función de control de las juntas y comisiones de licores, incluyendo una reducción de la publicidad y promoción del alcohol.

- Provisión de los recursos necesarios para la ejecución eficaz de estas medidas y para otras intervenciones eficaces ya ensayadas...

\section{CONCLUSIONES}

El ocio nocturno es un fenómeno en expansión (y no sólo en las sociedades occidentales), con resultados positivos para el progreso de la comunidad y el desarrollo de los individuos. No obstante, esta actividad presenta problemas específicos (accidentes de tráfico, consumo de drogas, violencia, etc.). Se ha probado una amplia gama de intervenciones, pero aún no contamos con la evaluación de los resultados. Es necesario investigar más a fondo los problemas derivados del ocio nocturno y los factores de riesgo y protección, sobre todo los vinculados al contexto y a las relaciones ambientales y socioculturales. Asimismo, se necesitan más estudios antes de hacer recomendaciones y redactar pautas. De especial interés es la eficacia de las intervenciones después de realizar el proceso de evaluación. the results are on the whole not significant, so that these alternatives cannot be recommended (Moreira, Smith and Foxcroft, 2009).

In summary, we should consider the cultural aspect as key. However, there is a need for well-directed research that describes and analyses cultural elements within their social reality in order to understand what sorts of intervention could be envisaged. A relevant question here is that ideology is of central significance. Interventions that will affect the recreational cultural background depend not only on the will or the skills of professionals, and indeed possibly depend more on societal changes.

\section{1. 'CLASSICAL' PREVENTION MEASURES}

The focus of the present review does not involve analysis of the effectiveness of classical measures, even though some reference has been made to them on analysing other interventions more directly related to nightlife recreational settings. Such classical interventions refer basically to the reduction of alcohol-related harm, but we are convinced that this type of intervention also has an effect on problems related to nightlife.

A short list of these interventions (Giesbrecht, 2008) would include:

- An increase in the real price of alcoholic beverages and a discontinuation of discount pricing and sale pricing.

- A ceiling and status quo on other types of availability hours and days of sale, density of on-premise and off-premise outlets.

- A rejuvenation of the control function of liquor boards and commissions that would include a reduction in alcohol marketing and promotion.

- Provision of the resources required for effective implementation of these measures and for other effective interventions already in place...

\section{CONCLUSIONS}

Nightlife is an expanding phenomenon -and not only in Western societies- with positive outcomes for the welfare of the community and for individual development. Nevertheless we can identify specific problems related to this activity (traffic accidents, abuse of drugs, violence, etc.). A wide range of interventions have been attempted, but there is still a lack of outcome evaluations. There is a need for more research on recreational nightlife-related problems and on risk and protective factors -especially in relation to context and environment and sociocultural relationships. Furthermore, more assessment is required before making recommendations and drawing up guidelines. Of particular cause for concern is the effectiveness of interventions after completion of the evaluation process. 
En estos ambientes las intervenciones no son sencillas ni fáciles de sistematizar, pues se trata de un sector muy dinámico. Pero la dificultad de lanzar intervenciones surge también por otros motivos muy diversos. Aún hay poca conciencia sobre los problemas de este sector. En general, la gente considera el ocio nocturno como algo positivo y no le gusta admitir los problemas. Señalar los problemas que se presentan en estos ambientes se ve en ocasiones como una crítica al derecho de los jóvenes a ser felices o, más aún, una crítica a los jóvenes por ser jóvenes.

En el ocio nocturno hay muchos sectores con intereses. En el caso de los profesionales de la prevención, su formación no suele tener que ver con estos ambientes. También hemos de tener en cuenta los debates ideológicos (muy intensos puesto que se trata de una situación totalmente nueva, con numerosas implicaciones culturales) sobre el fomento de determinadas iniciativas en detrimento de otras. Los enfoques iniciales de reducción de daños potenciaban las intervenciones que se limitaban a informar a los clientes sobre las consecuencias de su conducta por medio de folletos, análisis de pastillas, etc., pero sin cuestionar conductas individuales ni la estrategia de la industria. "Comprender la relación entre consecuencias positivas y negativas contribuye a redefinir las políticas que sean más eficaces a la hora de reducir las consecuencias negativas» (Graham, 2001).

Ya se han ido presentado conclusiones y comentarios sobre la eficacia de las intervenciones analizadas dentro de cada unos de los apartados correspondientes. Corresponde aquí hacer observaciones más generales:

1. Los esfuerzos de prevención se concentran casi siempre en las drogas ilegales. Sin embargo, la mayoría de los problemas surgen del consumo de alcohol o de la combinación del alcohol con otras drogas. Por tanto, la intervención debería concentrarse en el consumo de alcohol.

2. La cooperación es esencial. Como hemos dicho, a veces la industria del ocio nocturno no coopera, aunque en algunos países la colaboración es cada vez mayor. Los ayuntamientos y la policía también se retraen a la hora de cumplir con su deber. La burocracia municipal y los conflictos de intereses llevan muchas veces a la pasividad de estas instituciones. En el caso de la policia, aunque la investigación demuestra su eficacia, a menudo se resiste a intervenir. Los profesionales de la prevención y los investigadores deben buscar intervenciones innovadoras y realizar estudios prácticos para los responsables en tomar decisiones.

3. Intervenciones más populares en Europa y en todas partes se han basado durante muchos años en ofrecer información sobre la reducción de daños a los jóvenes clientes de los locales de ocio nocturno. En fechas más recientes, las intervenciones más populares han incluido servicios sobre la ingestion responsable de bebidas, la formación del personal de puertas (parte del SRB) y los programas de conductores designados, además de las conocidas intervenciones basadas en la información que recomiendan responsabilidad a la hora de beber o que explican estrategias individuales de reducción del daño.
Interventions in these settings are not simple or easy to systematize, since it is a highly dynamic sector. But the difficulties of launching interventions derive also from other and diverse sources. There is still little awareness about the problems related to this context. People in general tend to think very positively about nightlife, and don't like to see the problems. Pointing out the problems that emerge in these contexts is sometimes seen as questioning young people's right to happiness, or even questioning young people themselves.

Many stakeholders are involved in nightlife. In the case of prevention professionals, their training is not normally related to these settings. We must also take into account the ideological debates -all the more intense considering that this is quite a new situation, with many cultural implications- over the fostering of certain approaches over others. Some early harm-reduction approaches fostered interventions that merely informed patrons about the consequences of their behaviour through leaflets, pilltesting, etc., but without questioning either individual behaviour or industry strategy. "Understanding how positive and negative social consequences are linked may be helpful in fine-tuning policies to be maximally effective in reducing negative consequences" (Graham, 2001).

Conclusions and discussion about the efficacy and effectiveness of the interventions analysed and the problems related to them have been presented on addressing each one. Therefore, we shall make some more general comments:

1. Prevention efforts often concentrate on illegal drugs. However, most problems derive from the use of alcohol or the combination of alcohol with other drugs. Therefore, intervention should concentrate more on risky alcohol use.

2. Cooperation is essential. As we have already mentioned, there is sometimes a lack of cooperation from the nightlife industry, even if in some countries such collaboration is increasing. However, local councils and police are also often reluctant to go carry out their duties. Council bureaucracy and conflicts of interests frequently lead to passivity in these institutions. In the case of the police, even though research demonstrates their effectiveness, they can be reluctant to intervene. Prevention professionals and researchers should strive for innovative interventions and assessments that could be advantageous and practical for policy-makers.

3. The most popular types of interventions in Europe and elsewhere have for many years involved providing information on harm reduction to young people attending nightlife venues. More recently, the most popular interventions have included responsible beverage services, training of door staff (a part of the RBS) and designated driver programmes, apart from the wellknown information-based interventions recommending responsible drinking or explaining individual harmreduction strategies. Such popular interventions, most of them backed by the industry, are not exactly the most 
Estas intervenciones tan populares, en su mayoría respaldadas por la industria, no son precisamente las más eficaces, sobre todo existe una obligatoriedad. Los gerentes y empleados de los locales no aceptan voluntariamente u olvidan la intervención al cabo de un breve tiempo. Debería haber, como en otros sectores de la prevención, un claro compromiso con una intervención eficaz. Sin embargo, el uso frecuente de intervenciones tan populares como ineficaces contribuye a agravar el problema y a empañar la reputación de las medidas preventivas.

4. Mayor responsabilidad en la aplicación de la ley. Se trata claramente de una de las medidas más eficaces en sí (basta con que la policía visite los locales) o para reforzar un determinado conjunto de medidas, garantizando su ejecución. Pero la aplicación de la ley:

- necesita apoyo político y social.

- Es más fácil de llevar a la práctica cuando existe una conciencia social de los problemas (vandalismo, accidentes de tráfico con víctimas jóvenes que regresan de los centros de ocio, etc.).

5. Las intervenciones deben intentar cubrir áreas amplias para evitar que los clientes se desplacen de las zonas más exigentes normativamente a las que lo son menos. Es importante establecer criterios de calidad internacionales, puesto que muchos jóvenes van de vacaciones a centros internacionales de ocio nocturno. El establecimiento de criterios de calidad internacionales depende de la creación de una red exhaustiva y duradera a nivel local, nacional e internacional, en la que participen los países de origen de los turistas y los de destino.

6. La mayoría de las intervenciones son multicomponentes. En el caso de las intervenciones en los locales en los que se consume alcohol, se consigue mayor efecto combinando la formación de los empleados con la educación de los clientes, el desarrollo de políticas de reducción de riesgos y asegurar el cumplimiento de las normativas que disminuyan los riesgos derivados del alcohol (Graham, 2000). La mejor estrategia es la combinación de formación, cooperación y aplicación de la ley.

7. Los enfoques comunitarios son siempre intervenciones multicomponentes y producen los efectos más duraderos y significativos. Sin embargo, hay que tener en cuenta una serie de detalles:

- son caros.

- Necesitan apoyo político y social.

- A medio plazo hay problemas de cumplimiento y sostenibilidad.

8. Las medidas "clásicas» (subida de impuestos, restricción de las horas y días de venta, restricción de la densidad de los puntos de venta, controles de alcoholemia, reducción de los límites de alcohol en sangre, edad mínima para comprar alcohol, suspensión de la licencia administrativa y otras similares) se basan en la evidencia y son eficaces.

9. Urge hacer una valoración. Los recursos humanos y económicos no son ilimitados. El uso de intervenciones 0 estrategias ineficaces no sólo es un derroche de dinero, sino que además tiene un efecto perverso. Las perso- effective, especially if they are not enforced. Managers and staff often fail to volunteer or forget about the intervention after a short time. There should be, as in other sectors of prevention, a clear commitment to effective intervention. However, the highly frequent use of popular but ineffective interventions contributes more to the problem than to its solution, and only contributes to giving preventive efforts a bad reputation.

4. Greater accountability for law enforcement. This is clearly one of the most efficient measures in itself (police simply visiting recreational venues or reinforcing an agreed set of measures and ensuring their implementation). But law enforcement:

\section{- needs political and social support}

- is easiest to implement when there is local awareness of problems (vandalism, traffic accidents involving young people returning from nightlife venues, etc.).

5. Interventions should attempt to cover extensive areas, with a view to avoiding a situation in which clients move from more strictly regulated areas to others without so many rules. It is important to draw up international quality standards, since many young people like to go to international nightlife resorts for holidays. The setting-up of international quality standards would depend on the establishment of an in-depth and long-lasting network, at local, national and international levels, involving tourist providers as well as recipient countries.

6. Most interventions tend to be multi-component. In the case of on-premise interventions it seems likely that the main effects will be achieved by combining bar staff training, education of patrons, development of lowerrisk policies and enforcement of regulations aimed at decreasing risks related to drinking alcohol (Graham, 2000). What emerges as the best strategy is the combination of training, cooperation and enforcement.

7. Community approaches are typical multi-component interventions. They tend to produce the largest and most significant effects. However, there are some issues to take into account:

- they can be expensive

- they need political and society support

- in the medium term there are often problems with compliance and sustainability

8. 'Classical' measures (basically taxation, restriction of hours or days of sale, outlet density restrictions, sobriety checkpoints, reduced BAC limits, minimum legal purchasing age, administrative licence suspension and the like) are evidence based and effective.

9. Assessment is an urgent need. Human and economic resources are not limitless. The use of inefficient interventions or strategies is not only a waste of money, but can also have a perverse effect. The persons involved 
nas que participan en ellas tienen la sensación de que hacen algo útil y de que, por tanto, no es necesario buscar alternativas. Hay muchas razones para que sigan en marcha programas ineficaces (la autopercepción de que el programa es bueno debido a una determinada ideología, al temor a descubrir que lo que se ha hecho no sirve de nada, etc). Por otro lado, hay muchos intereses económicos en este contexto recreativo, lo cual subraya la importancia de las evaluaciones. Pero la evaluación requiere inversiones y estrategias experimentales correctas. Por ejemplo, después de dos décadas de SRB, aún no conocemos el contenido, formato y duración óptima de dicha formación (Graham, 2000).

10. Las nuevas tecnologías ofrecen muchas posibilidades de intervención, como la vigilancia por video, la verificación electrónica de la edad, o los dispositivos antiarranque de los coches para evitar que los conductores embriagados conduzcan. Pero Internet también ofrece posibilidades de establecer contactos, transmitir información sobre riesgos, etc., lo cual resulta útil.

11. Por último, pero no por ello menos importante, conviene centrarse en los aspectos culturales. Las drogas cumplen otras funciones simbólicas diferentes a las que tenían en la antigüedad. Tienden más bien a facilitar el vivir el momento, el presente, la inmediatez, el hedonismo... que son valores dominantes de la sociedad postmoderna. La vida de noche resume de forma paradigmática esta situación. Actualmente el individuo en nuestras sociedades está presionado tanto para trabajar como para divertirse, otorgando la significación necesaria para que ambas actividades se complementen coherentemente. La diversión es una gran industria y, por tanto, divertirse "es bueno" para el capitalismo. De hecho Jeremy Rifkin (2000) calculaba que para el año 2015 el sector del entretenimiento supondrá el 50\% del PIB norteamericano. Conviene estudiar con mayor profundidad las siguientes facetas: 1) la faceta económica-tendencias del mercado de trabajo, socioeconómicas y comerciales, flujos de símbolos, mercancías y consumidores; 2) la faceta constitucional-alcance y distribución de los poderes y las jurisdicciones; y 3 ) la faceta cultural-«redes complejas de intercambios comunicativos", que incluyen normas, tradiciones, relaciones y roles familiares y de género, y divisiones y cohesiones (Hadfield, 2009).

Muchas cuestiones pues están en liza y no sólo de tipo económico, sino también de orden social, ideológicas... Por poner un ejemplo, según unos «siempre que haya gente dispuesta a montar una fiesta, otros se opondrán, y la policía y los legisladores tendrán mucho trabajo. Es uno de los inconvenientes de la convivencia..., la vida nocturna es otro aspecto de la rueda disciplinaria cotidiana a la que los ciudadanos adultos deben someterse; con lo cual, parte de la inocencia y la magia del ocio nocturno se pierden" (Hadfield, 2009 ). Para otros, más pesimistas, "la diversión es la prolongación del trabajo bajo el capitalismo tardío. Es buscada por quien quiere sustraerse al proceso de trabajo mecanizado para poder estar de nuevo a su altura, en condiciones de afrontarlo... Del proceso de trabajo en la fábrica y en la oficina sólo have the feeling that they are busy doing something, so that there is no need to look for alternatives. There are many reasons why ineffective programs are still in use (self-perception that the program is good because of an ideology, fear of discovering that what has been done is ineffective, and so on). Moreover, there are many economic interests in this recreational context, making assessment even more important. However, assessment needs investment and correct experimental strategies. Despite two decades of RBS training, for example, we still do not know the optimal content, format and length of training (Graham, 2000).

10. New technologies open up many possibilities for interventions, such as video vigilance, 'pub watching', electronic age verification, or interlocks to prevent car driving by drunk drivers. But the Internet also offers possibilities for networking, information about risks, etc., that can be useful.

11. Last but not least, it is important to focus particularly on cultural aspects. Drugs fulfil symbolic functions different from those of previous eras. They tend more to facilitate "living the moment", experiencing the present, immediacy, hedonism..., which are the dominant values of post-modern society. The nightlife phenomenon summarizes this in paradigmatic fashion. The individual in today's society is pressurized not only to work but also to have fun, and both are given the necessary significance to complement one another in a coherent way. Entertainment is big business, so that having fun is "good" for capitalism. Indeed, Jeremy Rifkin (2000) calculated that by 2015 the entertainment sector will account for $50 \%$ of the United States' GDP. It may be that we need to explore in more depth the following three spheres: 1) the economic sphere-labour-market, socio-economic, and commercial trends, flows of symbols, commodities and consumers; 2 ) the constitutional sphere-the extent and distribution of powers and jurisdictions; and 3) the cultural sphere-'complex networks of communicative exchange' - including normative codes, traditions, family and gender relations and roles, and cultural divisions and cohesions (Hadfield, 2009).

Many questions, then, are on the table, and not only economic questions, but also those of a social and ideological nature, among others. By way of example, for some 'as long as some people want to party, then others will want to object and police and regulators will be kept busy. This appears to be one of the perennial challenges of living together..., nightlife becomes just another part of the daily disciplinary grind to which adult citizens must submit; thus, some of nightlife's innocence and magic is lost' (Hadfield, 2009). For others, more pesimist: 'Entertainment is the prolongation of work under late capitalism. It is sought by those who wish to extricate themselves from the process of mechanized work in order to be ready to confront it again. [...] Escape from the 
es posible escapar adaptándose a él en el ocio... La industria cultural ofrece como paraíso la misma vida cotidiana de la que se quería escapar. Huida y evasión están destinadas por principio a reconducir al punto de partida. La diversión promueve la resignación que se quisiera olvida precisamente en ella» (Horkheimer y Adorno, 1944).

Se escapa obviamente de las posibilidades de esta revisión seguir profundizando sobre estas cuestiones culturales y sobre las estrategias de actuación más adecuadas a la cultura recreativa nocturna. Pero seguramente en una primera fase lo que convendrá hacer es aumentar la información y la concienciación sobre esta realidad. Paralelamente hay que intentar conseguir una buena base científica para basar las políticas y las intervenciones.

\section{AGRADECIMIENTOS}

Esta investigación forma parte del proyecto Club Health (Diversión nocturna más saludable y segura; proyectoHP-101123-2008 12 11). Este proyecto es parcialmente financiado por la Comisión Europea (EAHC). process of work in the factory or in the office is only possible by adapting oneself to it in leisure time [...] The culture industry offers as a paradise the same everyday life from which one wishes to escape. Flight and evasion are by their very nature destined to lead us back to where we started. Entertainment brings about the resignation from which we are actually trying to escape through it' (Horkheimer and Adorno, 1944).

It is clearly beyond the brief of this review to go any deeper into the culture of fun and entertainment or into strategies of intervention on this type of culture. Undoubtedly, however, what is required in an initial phase is to increase information and awareness in relation to this reality. In parallel to this, we need a sound scientific basis for informing policy and intervention strategies.

\section{ACKNOWLEDGEMENTS}

This research is part of the project Club Health (Healthy and safer nightlife of youth; project-HP-101123-2008 12 11). This project is been financed by the European Commission (EAHC).

in reducing alcohol involvement in fatal motor carrier crashes. American Journal of Epidemiology, 170, 775-82

Briscoe S., Donnelly N. (2001). Assaults on Licensed Premises in InnerUrban Areas. Alcohol Studies Bulletin 2. Perth: Curtin University of Technology Western Australia National Drug Research Institute.

Brown, B. (1995). CCTV in Town Centres: Three Case Studies Police Research Group-Crime Disorder and Prevention Series Paper 68. London: The Home Office.

Buka, S. L. y Birdthistle, I. J. (1999). Long-term effects of a communitywide alcohol server training intervention. Journal of Studies on Alcohol, 60, 27-36.

Calafat, A., Bohrn, K., Juan, M., Kokkevi, A., Maal.sté, N., Mendes, F. et al. (1999). Night life in Europe and recreative drug use. Palma de Mallorca: Irefrea.

Calafat, A., Fernandez, C., Juan, M., Anttila, A., Arias, R., Bellis, M. A. et al. (2003). Enjoying nightlife in Europe. The role of moderation. Palma de Mallorca: Irefrea.

Calafat, A., Fernández, C., Juan, M. y Becoña, E. (2008). Recreational nightlife: Risk and protective factors for drug misuse among young Europeans in recreational environments. Drugs: education, prevention and policy, 15, 189-200.

Calafat, A., Blay, N., Juan, M., Adrover, D., Bellis, M.A., Hughes, K., Stocco, P., Siamou, I., Mendes, F. y Bohrn K (2009). Traffic risk behaviours at nightlife: drinking, taking drugs, driving and use of public transport by young people. Traffic injury prevention, 10, 162-169.

Calafat, A., Juan, M., Becoña, E. y Mantecón A. (2008). Que drogas se prefieren para las relaciones sexuales en contextos recreativos. Adicciones, 20, 37-48. 
Carmona, M. y Stewart, K. (1996). A Review of Alternative Activities and Alternative Programs in Youth-Oriented Prevention. CSAP Technical Report 13; DHHS Pub. No. SMA 96-3117. Rockville, MD: Center for Substance Abuse Prevention.

Chikritzhs, T., Catalano, P., Pascal, R. y Henrickson, N. (2007). Predicting alcohol-related harms from licensed outlet density: A feasibility study. Tasmania: National Drug Law Enforcement Research Fund.

Chikritzhs. T y Stockwell. T (2007). The impact of later trading hours for hotels (public houses) on breath alcohol levels of apprehended impaired drivers. Addiction, 102, 1609-17.

Collin, M. (1997). Altered State: The Story of Ecstasy Culture y Acid House. London: Serpent's Tail.

Department of Culture, Media y Sport. (DCMS) (2004). Draft Guidance issued under Section 182 of the Licensing Act 2003. Tabled Before Parliament on 23 March 2004. London: DCMS. Downloadable from: www.dcms.gov.uk

Doherty, S.J. y Roche, A.M. (2003). Alcohol and Licensed Premises: Best Practice in Policing. A Monograph for Police and Policy Makers. Payneham: Australasian Centre for Policing Research.

Dualibi, S., Ponicki, W., Grube, J. et al. (2007). The Effect of restricting opening hours on alcohol-related violence. American Journal. of Public Health, 97, 2276-2280.

EMCDDA (2006). Annual report 2006. Lisbon: EMCDDA.

EMCDDA (2006). Developments in drug use within recreational settings. Lisbon: EMCDDA.

EMCDDA (2009). Trends and availability of responses to drug use in recreational settings in Europe. Poster downloadable in http:// www.emcdda.europa.eu/attachements.cfm/att_78666_EN_ RES\%2020.pdf

Eurocare (2003). Drinking and Driving in Europe: A Eurocare Report to the European Union. Eurocare: Saint Ives, Cambridgeshire.

Faggiano, F. y Vigna-Taglianti, F. (2008). Drugs, Illicit - Primary Prevention Strategies. In: Kris Heggenhougen and Stella Quah (editors). International Encyclopedia of Public Health, Vol 2. San Diego: Academic Press.

Fell, J.C., Fisher, D.A., Voas, R.B., Blackman, K. y Tippetts, A.S. (2007). The relationship of 16 underage drinking laws to reductions in underage drinking drivers in fatal crashes in the United States. Annual Proceedings Association for the Advance of the Automotive Medicine, 51, 537-57.

Fernández-Hermida, J R, y Secades, R. (2003). Guía de referencia para la evaluación de programas de prevención de ocio alternativo. Gijón: Colegio Oficial de Psicólogos.

Forsyth. A.J.M. (2008). Banning glassware from nightclubs in Glasgow (Scotland): observed impacts, compliance and patrons views. Alcohol and Alcoholism, 43,111-117.

Forsyth, A.J.M. (2009). Lager, lager shouting': The role of music and DJs in nightclub disorder control. Adicciones, 21, 327-345.

Forsyth, A.J.M., Barnard, M. y McKeganey, N.P. (1997). Musical preference as an indicator of adolescent drug use. Addiction, 92, 1317-25.

Fountain, J. y Griffiths, P. (1997). Inventory, bibliography and synthesis of qualitative research in the European Union (Rep. No. 1). London: National Addiction Center.

Giesbrecht, N. (2008). Recent Developments in Overall Alcohol Consumption and High Risk Drinking: A Case for Effective Population Level Interventions in Canada. Adicciones, 20, 207-220.
Gliksman, L., McKenzie, D., Single. E., et al. (1993). The role of alcohol providers in prevention: an evaluation of a sever intervention programme. Addiction, 88, 1195-1203.

Goswami, N. (2004). Work ethic? They'll settle for a social life, thanks. The Sunday Times October 3, 2004. Retrieved in: http://www. timesonline.co.uk/article/0,2087-1291215,00.html

Graham, K. (2000). Preventive interventions for on-premise drinking: a promising but under researched area of prevention. Contemporary drug problems, 27, 593-668.

Graham, K. (2001). The ying and yang of alcohol intoxication: implications for research on the social consequences of drinking. Addiction, 98, 1021-1023.

Graham K., Bernards, S., Osgood, D. W., Homel, R. y Purcell, J. (2005). Guardians and handlers: the role of bar staff in preventing and managing aggression. Addiction, 100, 755-66.

Graham, K., Bernards, S., Osgood, D.W. y Wells, S. (2006). Bad nights or bad bars? Multi-level analysis of environmental predictors of aggression in late-night large-capacity bars and clubs. Addiction, 101, 1569-1580.

Graham K., LaRocque L., Yetman R., Ross T. J., Guistra E. (1980). Aggression and bar-room environments. Journal of Studies on Alcohol, 41, 468-85.

Graham, C.A., McLeod, L.S. y Steedman, D.J. (1998). Restricting extensions to permitted licensing hours does not influence the numbers of alcohol or assault related attendances at an inner city accident and emergency department. Journal of accident and emergency medicine, 15, 23-25.

Graham, K. y Wells, S. (2001). Aggression among young adults in the social context of the bar. Addiction Research, 9, 193-219.

Greater London Authority. (2002). Late night London: planning and managing the late night economy. London: Greater London Authority.

Gripenberg, J., Wallin, E. y Andreasson. S. (2007). Effects of a Community-Based Drug Use Prevention Program Targeting Licensed Premises. Substance use and misuse, 42,1183-1898.

Guéguen, N., Jacob, C., Le Guellec, H., Morineau, T. y Lourel, M. (2008). Sound level of environmental music and drinking behavior: a field experiment with beer drinkers. Alcoholism: clinical and experimental research, 32, 1-4.

Hadfield, P. (2009). Nightlife and Crime: Social. Order and Governance in International Perspective. Oxford: Oxford University Press.

Holder. H.D. y Wagenaar. A.C. (1994). Mandated server training and reduced alcohol-involved traffic crashes: a time series analysis of the Oregon experience. Accident analysis and prevention, 26, 89-97.

Holder, H.D., Gruenewald, P.J., Ponicki, W.R., Treno, A.J., Grube, J.B., Saltz, R.F. et al. (2000). Effect of community-based interventions on High Risk drinking and alcohol-related injuries. JAMA 284, 2341-47.

Home Office/KPMG LLP (2008). Review of the Social Responsibility Standards for the production and sale of alcoholic drinks. Birmingham: KPMG LLP. Retrieved from: http://drugs. homeoffice.gov.uk/publication-search/alcohol/alcohol-industryresponsibility/alcohol-industry-vol-3?view=Binary.

Homel, R., Carvolth, R., Hauritz, M. y Mcllwain G. (2004). Teague R. Making licensed venues safer for patrons: what environmental factors should be the focus of interventions? Drug and Alcohol Review, 23, 19-29. 
Homel, R. y Clark, J. (1994). The prediction and prevention of violence in pubs and clubs. Crime Prevention Studies, 3, 1-46.

Homel, R., Hauritz, M., Wortly, R., Mcllwain, G. y Carvolth, R. (1997). Preventing alcohol-related crime though community action: the surfers paradise safety action project. In Homel, R. (Ed.) Policing for prevention: reducing crime, public intoxication and injury. Monsey, NY: Criminal Justice Press.

Homel, R., Mcllwain, G. y Carvolth, R. (2001). Creating safer drinking environments. In: Heather N, Peters TJ, Stockwell T, eds. International handbook of alcohol dependence and problems. Chichester: John Wiley \& Sons, 721-40

Homel, R., Tomsen, S. y Thommeny, J. (1992). Public drinking and violence: not just an alcohol problem. Journal of Drug Issues, 22, 679-97.

Horkheimer, M. y Adorno, T.H. (1944). Dialektik der Aufklärung. Philosophische Fragmente. (Ed. en castellano (1998). Dialéctica de la llustración. Fragmentos filosóficos. Madrid: Trotta.

Hugues, K., Bellis, M., Calafat, A., Juan, M., Schnittzer, S. y Anderson, Z. (2008). Predictors of violence in young tourists: a comparative of British, German and Spanish holidaymakers. European Journal of Public Health, 18, 569-74.

Jeffs, B.W., Saunders, W.M. (1983). Minimizing Alcohol Related Offences by Enforcement of the Existing Licensing Legislation. British Journal of Addiction, 78, 67-77.

Jochelson, R. (1997). Crime and Place: An anysis of assaults and robberies in inner Sydney. Sydney: NSW Bureau of Crime Statistics and Research.

Jones, S.C. y Lynch, M. (2007). Non-advertising alcohol promotions in licensed premises: does the Code of Practice ensure responsible promotion of alcohol? Drug and Alcohol Review, 26, 477-85.

Ker, K. y Chinnock, P. (2008). Interventions in the alcohol server setting for preventing injuries, Cochrane Database Systematic Review, 16, 3, CD005244.

Krevor, B., Capitman, J.A., Oblak. L. et al. (2003). Preventing illegal tobacco and alcohol sales to minors through electronic ageverification devices: a field effectiveness study. Journal of Public Health Policy, 24, 251-268.

Lang, E. y Rumbold, G. (1997). The effectiveness of community based interventions to reduce violence in and around licensed premises: a comparison of three Australian models. Contemporary drug problems, 24, 805-826.

Lopez, A.D., Mathers, M.D., Ezzati, M., Jamison, D.T. y Murray, C. (2006). Measuring the Global Burden of Disease and Risk Factors, 19902001: The Global Burden of Disease and Risk Factors. New York: Oxford University Press.

Marsh, P. y Kibby, K. (1992). Drinking and Public Disorder. London: Portman Group.

MCM Research (2003). Implications for noise disturbance arising from the liberalisation of licensing laws: Report of research and consultation conducted by MCM Research Ltd for the Department for Environment, Food and Rural Affairs (Defra). London: MCM Research Ltd.

Maguire, M. y Nettleton, H. (2003). Reducing alcohol-related violence and disorder: an evaluation of the 'TASC' project. Home Office Research Study 265. London: Home Office.

Measham, F. (2004). The decline of ecstasy, the rise of 'binge' drinking and the persistence of pleasure. Probation Journal, 51, 309-326.
Measham, F. y Hadfield, P. (2009). Everything Starts with an 'E': Exclusion, ethnicity and elite formation in contemporary English clubland. Adicciones, 21,363-386.

Milich, R., Lynam, D.R., Zimmerman, R., Logan, T.K., Martin, C., Leukefeld, C.G., Portis, C., Miller, J. y Clayton, R. (2000). Differences in young adult psychopathology among drug abstainers, experimenters, and frequent users. Journal Substance Abuse, 11, 69-88.

Moreira, M.T., Smith, L.A. y Foxcroft, D. (2009). Cochrane Social norms interventions to reduce alcohol misuse in university or college students. Database Systematic Review, Jul 8, 3, CD006748.

Mosher, J.F., Toomey, T.L., Good, C., Harwood, E. y Wagenaar, A.C. (2002). State laws mandating or promoting training programs for alcohol servers and establishment managers: an assessment of statutory and administrative procedures. Journal of Public Health Policy, 23, 90-113.

Norman, E., Turner, S., Zunz, S. y Stillson, K. (1997). Prevention programmes reviewed: What works? In: E. Norman (Ed.), Drug free youth: A compendium for prevention specialists. New York: Garland.

Newton, A., Sharker, S.J., Pahal, G.S., van den Bergh, E. y Young, C. (2007). Impact of the new licensing law on emergency hospital attendances: a cohort study. Emergency Medicine Journal, 24, 532-534.

Parker, H. (2003). Pathology or modernity? Rethinking risk Factor analyses of young drug users. Addiction Research and Theory, $11,141-144$

Paschall MJ, Grube J W, Black C y Ringwalt C L. (2007). Is Commercial Alcohol Availability Related to Adolescent Alcohol Sources and Alcohol Use? Findings from a Multi-Level Study. Journal of Adolescent Health, 41, 168-174.

Philliber, S. (1999). Search of Peer Power: A Review of Research on Peer-Based Interventions for Teens. In Peer Potential: Making the Most of How Teens Influence Each Other. Washington, DC: National Campaign to Prevent Teen Pregnancy.

Quigley, B. M., Leonard K. E. y Collins R. L. (2003). Characteristics of violent bars and bar patrons. Journal of Studies on Alcohol, 64, 765-72.

Rabinovich, L., Brutscher, P., de Vries, H., Tiessen, J., Clift, J. y Reding, A. (2008). The affordability of alcoholic beverages in the European Union. Understanding the link between alcohol affordability, consumption and harms. Cambridge: Rand.

Rifkin, J. (2000). The Age of Access: The New Culture of Hypercapitalism. N. Y.: Penguin Group (USA).

Roberts, M. (2004). Good Practice in Managing the Evening and Late Night Economy: A Literature Review from an Environmental Perspective. London: Office of the Deputy Prime Minister. Retrieved from: http://www.communities.gov.uk/documents/ communities/pdf/131197.pdf

Roeper, Voas, R.B., Padilla-Sanchez. L. et al. (2000). A long-term community-wide intervention to reduce alcohol-related traffic injuries: Salinas, California, Drugs: education, prevention and policy, 7, 51-60.

Rothe, P.J. y Carroll, L.J. (2009). Hazards faced by young designated drivers: in-car risks of driving drunken passengers. International Journal of Environmental. Research Public Health, 6, 1760-77.

Shedler, J. y Block, J. (1990). Adolescent drug use and psychological health: A longitudinal inquiry. American Psychology, 45, 612630 . 
Schults, R., Elder, R.W., Sleet, D.A., Nichols, J.L., Alao, M.O., CarandeKulis, V.G. et al. (2001). Reviews of Evidence Regarding Interventions to Reduce Alcohol-Impaired Driving. American Journal of Preventive Medicine, 21, 4S.

Stockwell, T. and Chikritzhs, T. (2009). Do relaxed trading hours for bars and clubs mean more relaxed drinking? A review of international research on the impacts of changes to permitted hours of drinking. Crime Prevention and Community Safety, 11, 153-70.

Tay, R. (2005). Mass media campaigns reduce the incidence of drinking and driving. Evidence-based Healthcare Public Health, 9, 26-29.

Tossmann, P., Boldt, S. y Tensil, M. D. (2001), 'The use of drugs within the techno party scene in European metropolitan cities', European Addiction Research, 7, 2-23.

Treno, A.J., Lee, J.P., Freisthler, B., Remer, L.G. y Gruenewald, P.J. (2005). Application of evidence-based approaches to community interventios. In Stockwell, T., Gruenewald, P.J., Toumbourou, J.W., Loxley, W. (Eds), Preventing Harmful Substance Use: the Evidence Base for Policy and Practice. West Sussex: John Wiley \& Sons

Van Sassenbroeck, D.K., Calle, P.A., Rousseau, F.M., Verstraete, A.G., Belpaire, F.M., Monsieurs, K.G. et al. (2003). Medical problems related to recreationaldrug use at nocturnal dance parties. European Journal of Emergency Medicine, 10, 302-8.

Villar, J.A. (2008). Ibiza: beauty of the day, queen of the night: the influence of clubbing on the Ibizan population. Proceedings from Club Health Conference Ibiza.

Wagenaar. A.C, Murray. D.M y Toomey. T.L (2000). Communities mobilizing for change on alcohol (CMCA): effects of a randomized trial on arrests and traffic crashes. Addiction, 95, 209-217.

Wagenaar, A.C., Toomey, T.L. y Erickson. D.J. (2005). Preventing youth access to alcohol: outcomes from a multi-community timeseries trial. Society for the study of Addiction, 100, 335-345
Wallin, E. y Andréasson, S. (2005). Effects of a community action program on problems related to alcohol consumption at licensed premises. In Stockwell, T., Gruenewald, P.J., Toumbourou, J.W., Loxley, W. (Eds), Preventing Harmful Substance Use: the Evidence Base for Policy and Practice. West Sussex: John Wiley \& Sons.

Warburton, A. L. y Shepherd, J. P. (2000). Effectiveness of toughened glassware in terms of reducing injury in bars: a randomised controlled trial. Injury Prevention, 6, 36-40.

Warburton. A.L. y Shepard, J.P. (2005). Tackling alcohol related violence in city centres: effect of emergency medicine and police intervention. Emergency Medical Journal, 23,12-17.

Wells, S., Graham, K. y West, P. (1998). 'The good, the bad and the ugly': responses by security staff to aggressive incidents in public drinking settings. Journal of Drug Issues, 28, 817-36.

Willis, C., Lybrand, S. y Bellamy, N. (2004). Alcohol ignition interlock programmes for reducing drink driving recidivism. Cochrane Database of Systematic Reviews, 4, CD004168

Wilkins, C. y Sweetsur, P. (2009). Differences in harm from legal BZP/ TFMPP party pills between North Island and South Island users in New Zealand: A case of effective industry self-regulation? International Journal of Drug Policy (in press).

Wood. D.W, Greene. S.L, Alldus. G., Huggett, D., Nicolaou, M., Chapman, K. et al. (2008). Improvement in the pre-hospital care of recreational drug users through the development of club specific ambulance referral guidelines. Substance abuse treatment, prevention and policy, 3: 14. doi: 10.1186/1747597X-3-14.

Worpole, K. (1992). Towns For People: Transforming Urban Life. Buckingham: Open University Press.

Zhu, L., Gorman, D.M., y Horel, S. (2004). Alcohol outlet density and violence: A geospatial analysis. Alcohol and Alcohology 39, 369-375. 
